\title{
Flavonoids: modulators of brain function?
}

\author{
Jeremy P. E. Spencer* \\ Molecular Nutrition Group, School of Chemistry, Food and Pharmacy, University of Reading, Reading RG2 6AP, UK
}

Emerging evidence suggests that dietary phytochemicals, in particular flavonoids, may exert beneficial effects on the central nervous system by protecting neurons against stress-induced injury, by suppressing neuroinflammation and by improving cognitive function. It is likely that flavonoids exert such effects, through selective actions on different components of a number of protein kinase and lipid kinase signalling cascades, such as the phosphatidylinositol-3 kinase (PI3K)/Akt, protein kinase $\mathrm{C}$ and mitogen-activated protein kinase (MAPK) pathways. This review explores the potential inhibitory or stimulatory actions of flavonoids within these pathways, and describes how such interactions are likely to underlie neurological effects through their ability to affect the activation state of target molecules and/or by modulating gene expression. Future research directions are outlined in relation to the precise site(s) of action of flavonoids within signalling pathways and the sequence of events that allow them to regulate neuronal function.

Flavonoids: brain: cognitive function: neurodegeneration: cell signalling

Representing one of the most important lifestyle factors, diet can strongly influence the incidence and onset of cardiovascular and neurodegenerative diseases, and thus a healthy diet is an essential factor for healthy ageing. Various phytochemical constituents of foods and beverages, in particular a class of photochemicals known as flavonoids, have been avidly investigated in recent years. A number of dietary intervention studies in humans and animals, in particular those with foods and beverages derived from Vitis vinifera (grape), Camellia sinensis (tea), Theobroma cacao (cocoa) and Vaccinium spp. (blueberry) have demonstrated beneficial effects on vascular function and mental performance. While such foods and beverages differ greatly in chemical composition, macro- and micro-nutrient content and caloric load per serving, they have in common that they are amongst the major dietary sources of flavonoids. Dietary intervention studies in several mammalian species, including humans, using flavonoid-rich plant or food extracts have indicated an ability of these dietary components to improve memory and learning ${ }^{(1-7)}$, by protecting vulnerable neurons, enhancing existing neuronal function or by stimulating neuronal regeneration. Their neuroprotective potential has also been demonstrated in both oxidative stress- ${ }^{\left({ }^{8}\right)}$ and $A \beta$-induced-neuronal death models ${ }^{(9)}$ and evidence supports the beneficial and neuromodulatory effects of flavonoid-rich ginkgo biloba extracts, particularly in connection with age-related dementias and Alzheimer's disease ${ }^{(9-11)}$. Furthermore, the citrus flavanone, tangeretin, has been observed to help maintain nigrostriatal integrity and functionality following lesioning with 6-hydroxydopamine, suggesting that flavonoids may also serve as potential neuroprotective agents against the underlying pathology associated with Parkinson's disease ${ }^{(12)}$.

Historically, the biological actions of flavonoids have been attributed to their antioxidant properties, either through their reducing capacities per se or through their possible influences on intracellular redox status ${ }^{(13)}$. However, it has been speculated that their classical hydrogen donating antioxidant activity cannot explain the bioactivity of flavonoids in vivo. Indeed, it has become evident that flavonoids are more likely to exert their neuroprotective actions by (1) the modulation of intracellular signalling cascades which control neuronal survival, death and differentiation; (2) affecting gene expression and (3) interactions with mitochondria ${ }^{(14-16)}$. This review will emphasize the potential of flavonoids to exert beneficial effects in the brain by preventing neurodegeneration, inhibiting neuroinflammation and reducing age-related cognitive decline. In particular, it will highlight probable mechanisms which underpin such actions in the brain, including their interactions with neuronal intracellular signalling pathways vital in determining neuronal death, survival, differentiation and proliferation.

\section{Flavonoid structure, source and metabolism}

Flavonoids comprise the most common group of polyphenolic compounds in the human diet and are found ubiquitously in

Abbreviations: MAPK, mitogen-activated protein kinase; ERK, extracellular signal-regulated protein kinase; JNK, c-Jun N-terminal kinase; PI3K, phosphatidylinositol-3 kinase; PKB, protein kinase B; PKC, protein kinase C; ASK1, apoptosis signal-regulating kinase 1; STAT-1, signal transducer and activator of transcription-1; AP-1, activated protein-1; CREB, cAMP response element-binding protein; ATF-1/2, activating transcription factor 1/2; MSK1, mitogen- and stress-activated protein kinase 1; mTOR, mammalian target of rapamycin; p47 ${ }^{\text {phox }}$, NADPH oxidase (p47 cytoplasmic element; p90RSK (RSK), $90 \mathrm{kDa}$ ribosomal S6 kinase; MEF-2, myocyte enhancer factor 2; DSP, dual specificity phosphatase; PTEN, phosphatase and tensin homologue deleted on chromosome ten; LPS, lipopolysacharide; IL-1 $\beta$, interleukin- $1 \beta$; iNOS, inducible nitric oxide synthase; eNOS, endothelial nitric oxide synthase; IFN- $\gamma$, interferon gamma; LDL, low-density lipoprotein; NO; nitric oxide; TNF- $\alpha$, tumour necrosis factor-alpha; BBB, blood-brain barrier; CNS, central nervous system. * Corresponding author: Dr J. P. E. Spencer, fax +44 118931 0080, email j.p.e.spencer@reading.ac.uk 
plants. Major dietary sources of flavonoids include fruits, vegetables, cereals, tea, wine and fruit juices [reviewed in ${ }^{(17)}$ ]. Flavonoids consist of two aromatic carbon rings, benzopyran ( $\mathrm{A}$ and $\mathrm{C}$ rings) and benzene ( $\mathrm{B}$ ring), and may be divided in six subgroups based on the degree of the oxidation of the C-ring, the hydroxylation pattern of the ring structure and the substitution of the 3-position. The main dietary groups of flavonoids are (1) flavonols (e.g. kaempferol, quercetin), which are found in onions, leeks, broccoli, (2) flavones (e.g. apigenin, luteolin), which are found in parsley and celery, (3) isoflavones (e.g. daidzein, genistein), which are mainly found on soy and soy products, (4) flavanones (e.g. hesperetin, naringenin), which are mainly found in citrus fruit and tomatoes, (5) flavanols (e.g. catechin, epicatechin, epigallocatechin, epigallocatechin gallate (EGCG), which are abundant in green tea, red wine, chocolate, and (6) anthocyanidins (e.g. pelargonidin, cyanidin, malvidin), whose sources include red wine and berry fruits. Further information regarding the structure and classes of flavonoids may be found in the thorough review by Manach et al. ${ }^{(17)}$

Although flavonoids display potent antioxidant capacity in vitro ${ }^{(13,18,19)}$, during absorption they are extensively metabolised, resulting in significant alteration of their redox potentials. For example, the majority of flavonoid glycosides, and in some instances the aglycones, present in plant-derived foods, are extensively conjugated and metabolised during absorption [reviewed in ${ }^{(20-24)}$ ]. In particular, there is much evidence for the extensive phase I de-glycosylation and phase II metabolism of the resulting aglycones to glucuronides, sulphates and $O$-methylated forms during transfer across the small intestine ${ }^{(20,25)}$ and then again in the liver. Further transformation has been reported in the colon where the enzymes of the gut microflora degrade flavonoids to simple phenolic acids ${ }^{(26)}$. In addition, flavonoids may undergo at least three types of intracellular metabolism: (1) oxidative metabolism, (2) P450-related metabolism and (3) conjugation with thiols, particularly $\mathrm{GSH}^{(27,28)}$. Circulating metabolites of flavonoids, such as glucuronides, sulphates and conjugated $O$-methylated forms, or intracellular metabolites like flavonoid-GSH adducts, have greatly reduced antioxidant potential ${ }^{(28)}$. Indeed, studies have indicated that although such conjugates and metabolites may participate directly in plasma antioxidant reactions and in scavenging reactive oxygen and nitrogen species in the circulation their effectiveness is reduced relative to their parent aglycones ${ }^{(29-33)}$.

\section{Do flavonoids access the brain?}

In order to understand whether flavonoids and their metabolic derivatives are capable acting as neuromodulators, it is crucial to ascertain whether they are able to enter the central nervous system. In order for flavonoids to enter into the brain, they must first cross the blood-brain barrier (BBB). The functions of the BBB include controlling the entry of xenobiotics into the brain and maintenance of the brain's microenvironment ${ }^{(34)}$. In vitro and in vivo studies have indicated that the flavanones hesperetin, naringenin and their relevant in vivo metabolites, as well as some dietary anthocyanins, cyanidin3-rutinoside and pelargonidin-3-glucoside, are able to traverse the $\mathrm{BBB}^{(35-37)}$. Furthermore, it appears that the potential for flavonoid penetration is dependent on compound lipophilicity ${ }^{(35)}$. Accordingly, it is plausible that the uptake of the less polar $O$-methylated metabolites, such as the $O$-methylated epicatechin metabolites (formed in the small intestine and liver), may be greater than the parent aglycone. For the same reason, the more polar glucuronidated metabolites, which have lower BBB permeability values ${ }^{(35)}$, may not be able to access the brain. However, evidence exists to suggest that certain drug glucuronides may cross the $\mathrm{BBB}^{(38)}$ and exert pharmacological effects ${ }^{(39,40)}$, suggesting that there may be a specific uptake mechanism for glucuronides in vivo. Apart from the flavonoids lipophilicity, their ability to enter the brain may also be influenced by their interactions with specific efflux transporters expressed in the BBB. One such transporter is $\mathrm{P}$-glycoprotein, which plays an important role in drug absorption and brain uptake ${ }^{(41)}$ and appears to be responsible for the differences between naringenin and quercetin flux into the brain in situ ${ }^{(37)}$.

Animal feeding studies also indicate that flavonoids may access the brain, with the tea flavanol, EGCG, being reported to access the brain after oral administration to mice ${ }^{(42)}$. Furthermore, oral ingestion of pure epicatechin resulted in the detection of epicatechin glucuronide and $3^{\prime}$-O - -methyl-epicatechin glucuronide in rat brain tissue ${ }^{(43)}$. Anthocyanidins have also been detected in the brain after oral administration ${ }^{(44,45)}$, with several anthocyanidins being identified in different regions of rat brain after the animals were fed with blueberry ${ }^{(46)}$. Such flavonoid localisation has been correlated with increased cognitive performance, suggesting a central neuroprotective role of these components. Despite their apparent ability to access the brain, it is clear that the concentrations of flavonoids and their metabolite forms accumulated in vivo ${ }^{(43)}$ are lower (high $\mathrm{nM}$, low $\mu \mathrm{M}$ ) than those recorded for small molecule antioxidant nutrients such as ascorbic acid and $\alpha$-tocopherol ${ }^{(47)}$. Consequently, the beneficial effects of flavonoid metabolites in vivo are unlikely to result due to their ability to out-compete antioxidants such as ascorbate, which are present at higher concentrations (high $\mu \mathrm{M}$ to $\mathrm{mM}$ ). However, evidence has accumulated to suggest that the cellular effects of flavonoids may be mediated by their interactions with specific proteins central to intracellular signalling cascades $^{(16)}$, such as the mitogen-activated protein kinase (MAP kinase) signalling pathway and the phosphoinositide 3-kinase (PI3 kinase/Akt) signalling cascade (Fig. 1).

\section{Improvement in memory, learning and cognitive performance}

There is a growing interest in the potential of phytochemicals to improve memory, learning and general cognitive ability. Previous studies have indicated that phytochemical-rich foods such as berries and spinach are effective at reversing age-related deficits in motor function and spatial working memory ${ }^{(3,48-54)}$ For example, the latency period to find a platform and the distance swam to a platform in a Morris water maze task, are significantly reduced following blueberry supplementation ${ }^{(48,49)}$. Such results may suggest favourable effects of the blueberry diet on locomotor activity in old animals ${ }^{(46,55)}$. However, reductions in the time taken to make a choice may also reflect an improved memory component, where rats 'remembered' more rapidly and thus responded quicker. Presently, it is unclear how phytochemicals may exert such effects, although 


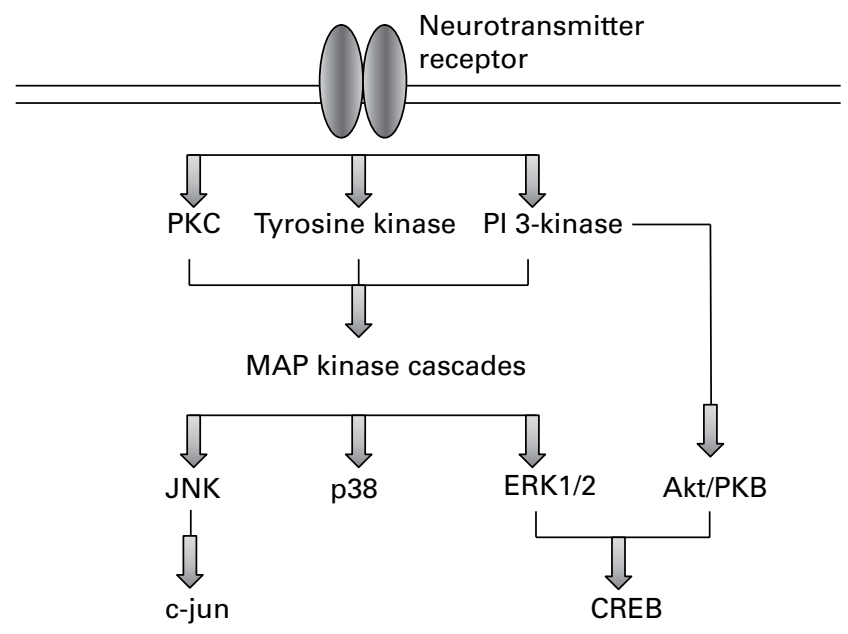

Neuronal apoptosis Neuronal survival and plasticity

Fig. 1. Overview of MAP kinase and Akt/PKB signalling cascades in neurons. Flavonoid-induced activation of ERK $1 / 2$ or PI3K/Akt pathways acts to stimulate neuronal survival and/or enhance synaptic plasticity and long-term potentiation relevant to the laying down of memory. In addition, inhibitory actions within JNK and p38 pathways are likely to be neuroprotective in the presence of stress.

they may be linked to antioxidant actions, the modulation of neurotransmitter release ${ }^{(48,49)}$, the stimulation of hippocampal neurogenesis ${ }^{(50)}$ via the modulation of signalling ${ }^{(52,53)}$ or an ability to improve cerebrovascular blood flow ${ }^{(56)}$.

Flavonoid-rich foods, in particular those containing flavanols, have been observed to improve peripheral blood flow
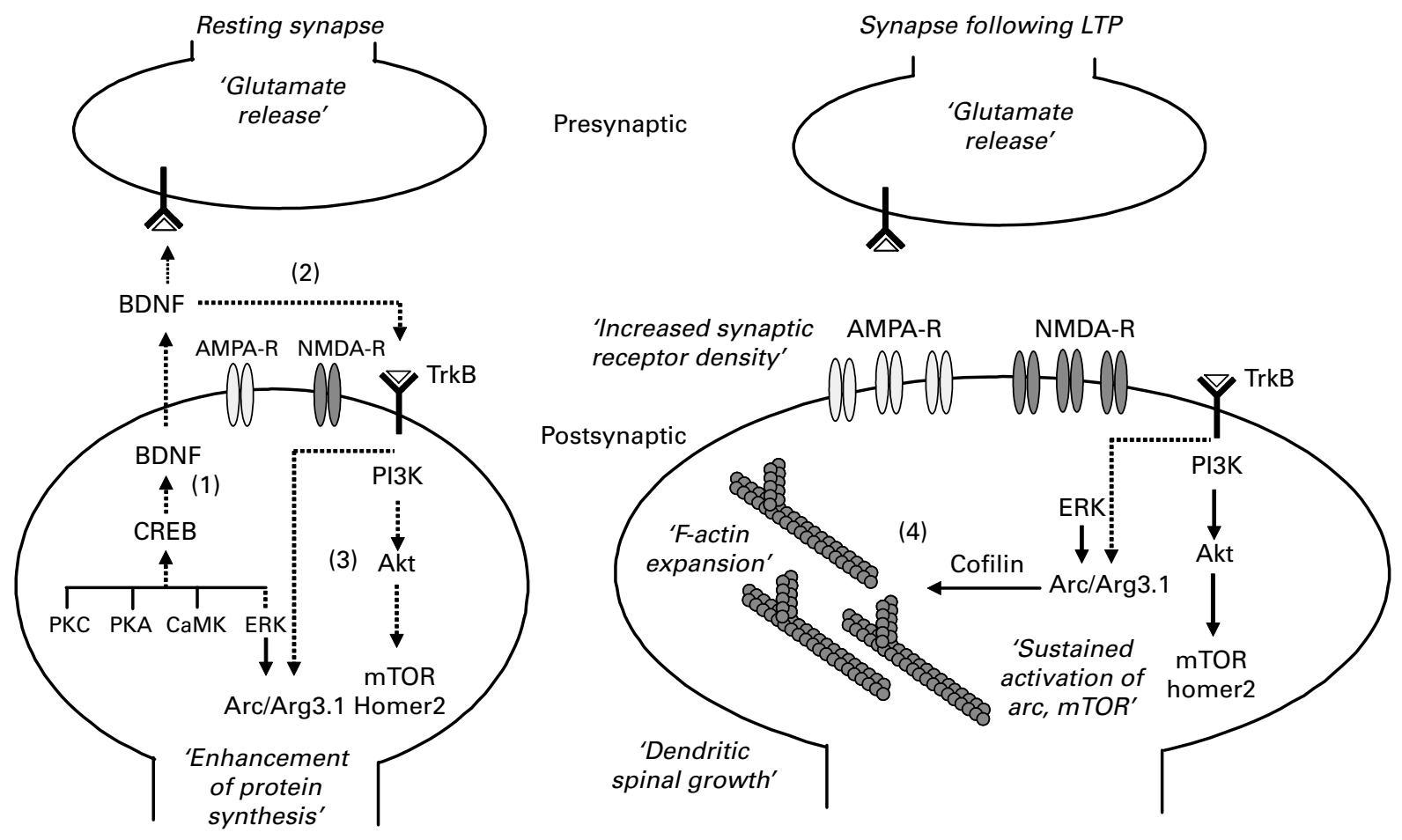

Fig. 2. Formation of stable long-term potentiation at synapses. (1) Increased expression and release of BDNF from the synapse through enhanced CREB activation. BDNF binds to pre- and post-synaptic TrkB receptors (2), triggering glutamate release and PI3K/mTOR signalling and Arc synthesis (3). Sustained activation of mTOR leads to enhanced translational efficiency whilst Arc, in association with Cofilin, triggers F-actin expansion and synapse growth (mushroom synapse) (4).

and surrogate markers of cardiovascular function in humans ${ }^{(56)}$. In the context of the CNS, brain imaging studies in humans have demonstrated that the consumption of flavanol-rich cocoa may enhance cortical blood flow ${ }^{(57,58)}$. Increased cerebrovascular function, especially in the hippocampus, a brain region important for memory, may facilitate adult neurogenesis ${ }^{(59)}$. Indeed, new hippocampal cells are clustered near blood vessels, proliferate in response to vascular growth factors and may influence memory ${ }^{(60)}$. As well as new neuronal growth, increases in neuronal spine density and morphology are considered vital for learning and memory $^{(61)}$. Changes in spine density, morphology and motility have been shown to occur with paradigms that induce synaptic, as well as altered sensory experience, and lead to alterations in synaptic connectivity and strength between neuronal partners, affecting the efficacy of synaptic communication. These events are mediated at the cellular and molecular level and are strongly correlated with memory and learning (Fig. 2).

The enhancement of both short-term and long-term memory is controlled at the molecular level ${ }^{(62)}$. Whereas short-term memory involves covalent modifications of pre-existing proteins, long-term memory requires the synthesis of new mRNAs and proteins ${ }^{(63,64)}$. Four signalling pathways control this process: (i) cAMP-dependent protein kinase (protein kinase A), (ii) calcium-calmodulin kinases, (iii) protein kinase $\mathrm{C}$, and (iv) mitogen-activated protein kinase (MAPK). All four pathways converge to signal to the cAMP-response element-binding protein (CREB), a transcription factor which binds to the promoter regions of many genes associated with memory and synaptic plasticity ${ }^{(65,66)}$ (Fig. 2). The importance

(1)


of CREB activation in the induction of long-lasting changes in plasticity and memory are highlighted by studies which show that disruption of CREB activity specifically blocks the formation of long-term memory ${ }^{(67)}$, whereas agents that increase the amount or activity of CREB accelerate the process ${ }^{(68)}$. Furthermore, robust CREB phosphorylation and CRE-reporter gene expression are detected in cortical neurons during developmental plasticity ${ }^{(69)}$ and in hippocampal neurons in response to both LTP-inducing stimuli and memory training tasks ${ }^{(70,71)}$. There is considerable interest in identifying safe effective agents that enhance the activity of CREB, as these may lead to an improvement in memory.

Previous studies have suggested that phytochemicals, especially flavonoids, may exert cellular effects via direct modulation of protein and lipid kinase signalling pathways ${ }^{(14)}$. Interactions within the MAPK pathway are thought to be central to mediating the cellular effects of flavonoids such as those found in berries, tea and $\operatorname{cocoa}^{(15,72)}$. For example, the flavanol, (-)-epicatechin, induces both ERK1/2 and CREB activation in cortical neurons and subsequently increases CREB regulated gene expression ${ }^{(73)}$ (Fig. 1). Furthermore, another flavonoid, fisetin, has recently been shown to improve long-term potentiation (LTP) and memory through a CREB/ ERK mechanism ${ }^{(74)}$. Thus, one potential mechanism action of flavonoids in modulating neuronal function, synaptic plasticity and synaptogenesis may proceed via signalling through CREB. If flavonoids are able to promote neuronal activation of CREB in vivo they may be capable of influencing the neuronal expression of a number of genes which contain cAMPresponse element (CRE) sequences in their promoter regions ${ }^{(75)}$. Particular emphasis has been given to the regulation of $\mathrm{BDNF}^{(76,77)}$, which has been implicated in synaptic plasticity and long-term memory ${ }^{(78)}$ and is robustly induced in hippocampal neurons upon synaptic stimulation ${ }^{(79)}$. BDNF belongs to the neurotrophin family of growth factors and affects the survival and function of neurons in the central nervous system. Its secretion from neurons is under activitydependent control and is crucial for the formation of appropriate synaptic connections during development and for learning and memory in adults ${ }^{(80)}$. Decreases in BDNF and pro-BDNF have been reported in Alzheimer's disease ${ }^{(81,82)}$ and the importance of pro-BDNF has been emphasized by the finding that a polymorphism that replaces valine for methionine at position 66 of the pro-domain is associated with memory defects and abnormal hippocampal function in humans ${ }^{(83)}$. In addition, genetic ${ }^{(84)}$ as well as pharmacological inhibition $^{(85)}$ of BDNF or its receptor, tropomyosin receptor kinase B $(\text { TrkB })^{(86)}$, impairs learning and memory. On the other hand, agents that increase in BDNF levels may lead to improvements in spatial working memory, in part through the regulation of protein translation via the mTOR signalling pathway ${ }^{(87)}$ (Fig. 2). BDNF is known to bind to the TrkB receptor either pre- or post-synaptically causing activation of the PI3 kinase/Akt signalling pathway, the phosphorylation of mTOR at $\mathrm{Ser}^{2448}$, the phosphorylation of NMDA receptors and the release of neurotransmitters from pre-synaptic sites ${ }^{(88)}$.

Many of the BDNF-regulated mRNAs in mature neurons encode proteins that function at synapses ${ }^{(78)}$. One such protein which is associated with LTP is activity-regulated cytoskeletal-associated protein, $\operatorname{Arc} / \operatorname{Arg} 31$, which has been proposed to be under regulatory control of both $\mathrm{BDNF}^{(89)}$ and the ERK signalling pathway ${ }^{(90)}$. Sustained synthesis of Arc/ Arg3.1 during a protracted time-window is necessary to consolidate LTP, whilst translation of pre-existing Arc/ Arg3.1 mRNA contributes to early LTP expression and translation of new Arc/Arg3.1 mRNA mediates consolidation ${ }^{(91)}$. Increased Arc/Arg3.1 expression may facilitate changes in synaptic strength, and the induction of morphological changes, such as that observed when small spines are converted into large mushroom-shaped spines through a mechanism dependent on actin polymerization ${ }^{(92)}$ (Fig. 2). Whether flavonoids are able to promote changes in neuronal morphology in vivo, via signalling through these pathways is currently unknown. However, the ability of flavonoids and their in vivo metabolites to exert effects on neuronal signalling cascades (dealt with in greater depth later in this review) suggest that they may be capable of inducing behavioural changes in memory, learning and cognitive performance through interactions with such pathways. In agreement with this, previous studies have indicated that certain flavonoids may influence neuronal dentrite outgrowth in vitro ${ }^{(93)}$.

\section{Inhibition of neuroinflammation}

There is increasing evidence to suggest that neuroinflammatory processes may contribute to the cascade of events leading to the progressive neuronal damage observed in Parkinson's disease and Alzheimer's disease ${ }^{(94,95)}$, and also with the neuronal injury associated with stroke ${ }^{(96)}$. In support of this, observations suggest that the use of non-steroidal anti-inflammatory drugs, such as ibuprofen, may delay or even prevent the onset of neurodegenerative disorders, such as Parkinson disease ${ }^{(97,98)}$. Activation of glial cells (astrocytes and microglia) plays a key role in the development of inflammatory neurodegeneration $^{(99)}$. Glial cells occupy the majority of the brain volume and play a key role in the maintenance of brain integrity and upon appropriate activation, glia respond to invading pathogens, eliminate cellular debris and promote cell repair and recovery ${ }^{(100,101)}$. However, excessive and chronic activation of glial cells may have harmful effects by triggering an inflammatory response that ultimately leads to progressive neuronal degeneration ${ }^{(102)}$. Central to glial-induced neurotoxicity is the generation of $\mathrm{NO}^{\circ}$ via increases in the expression of iNOS (Fig. 3). The production of $\mathrm{NO}^{\circ}$ by glial cells is mediated by iNOS, and excessive NO may diffuse away from glial cells and induce neuronal cell damage by disrupting neuronal mitochondrial electron transport chain (ETC) function $^{(103)}$ (Fig. 3). In particular, NO may selectively inhibit mitochondrial respiration at cytochrome $c$ oxidase (complex IV) resulting in a disruption of neuronal adenosine $5^{\prime}$-triphosphate (ATP) synthesis and an increased generation of $\operatorname{ROS}^{(104)}$. Therefore, the uncontrolled activation of iNOS in glial cells is a critical step in inflammatory-mediated neurodegeneration. Inflammation is also characterised by increased cytokine production, such as IL- $1 \beta$ and TNF- $\alpha$, which also act to stimulate iNOS and NO production ${ }^{(105)}$, and by the activation of NADPH oxidase which generates superoxide $\left(\mathrm{O}_{2}^{-}\right)$and hydrogen peroxide $\left(\mathrm{H}_{2} \mathrm{O}_{2}\right)^{(106)}$.

Importantly, the transcriptional and post-transcriptional regulation of iNOS and cytokines in activated glial cells is dependent on signalling through pathways such as MAPK, specifically through activation of ERK1/2 $2^{(107-110)}$ (Fig. 4). 


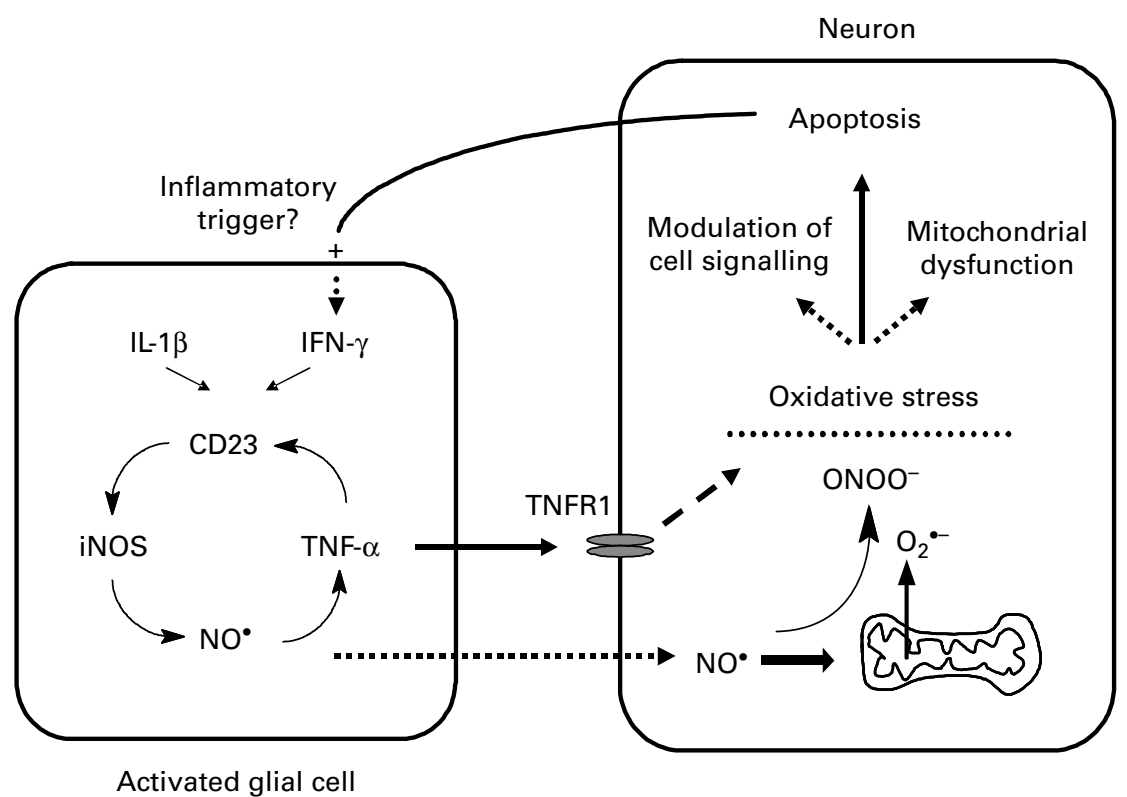

Fig. 3. Involvement of activated glial cells in neuroinflammation-induced neurodegeneration. Central to glial-induced neurotoxicity is the generation of NO via increases in the expression of iNOS. iNOS itself is induced by the cell surface CD23 receptor which is in turn activated by cytokines such as TNF- $\alpha$ and IL-1 $\gamma$. NO may diffuse to neighbouring neurons where it inhibits mitochondrial respiration at cytochrome $c$ oxidase. NO may also react with $\mathrm{O}_{2}^{-}$to generate $\mathrm{ONOO}^{-}$ which can cause damage to proteins, inhibit mitochondrial respiration and activate cell death genes and signalling pathways which may ultimately lead to neuronal death. Furthermore, cytokines such as TNF- $\alpha$ may cause direct cell death by binding to specific receptors expressed in neurons and subsequently activate genes that trigger the apoptotic pathway.

These observations suggest that pharmacological control of such signalling pathways may be a useful tool in the prevention/treatment of neurodegenerative diseases through their ability to modulate glial cell activation. The MEK inhibitor PD98059, which has significant structural homology with flavonoids, has been shown to effectively block iNOS expression and generation of $\mathrm{NO}^{\cdot(108)}$, suggesting that flavonoids may also be capable of exerting anti-inflammatory actions via inhibitory

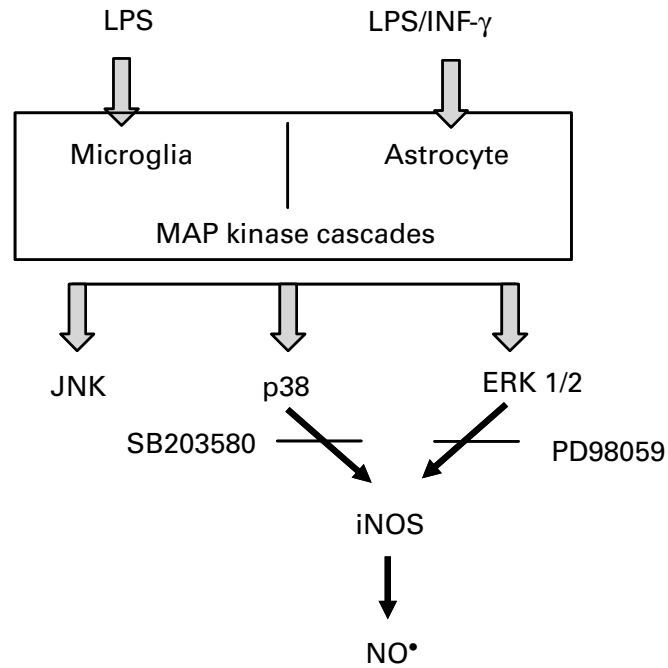<smiles>O=c1c(O)c(-c2ccc(O)c(O)c2)oc2cc(O)cc(O)c12</smiles>

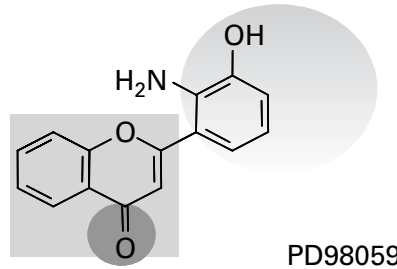

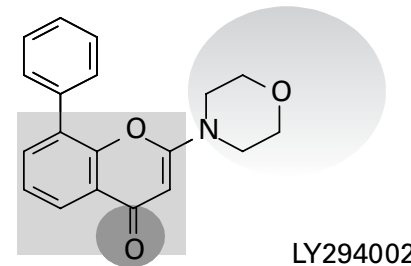

Fig. 4. Structural homology of flavonoids with specific pathway inhibitors. Use of specific MAPK inhibitors such as SB203580 and PD98059 inhibit the transcriptional regulation of iNOS in activated glial cells. Interestingly, the structure of PD98059 and other kinase inhibitors have close structural homology to that of flavonoids. It is therefore possible that flavonoids may modulate neuroinflammation by interfering with cell signalling pathways such as MAPK. 
actions on MEK1 within the ERK signalling pathway (Fig. 4). Thus far, studies have indicated that flavanols ${ }^{(111,112)}$, flavones $^{(113-117)}$, and flavonols ${ }^{(118)}$ are capable of inhibiting the release of $\mathrm{NO}^{\circ}$ by activated microglia via the down-regulation of iNOS gene expression. However, it is not known if such effects are mediated by changes in signalling through ERK, or any other MAPK, thus further investigation is warranted. The modulation of glial signalling cascades and pro-inflammatory transcription factors as well as cytokines and $\mathrm{NO}^{\circ}$ production may result in a suppression of neuroinflammation and ultimately to protection against neurodegeneration. It is plausible that the development of novel therapeutic agents or a cocktail of drugs that target neuroinflammation at various stages may act to reduce neurodegeneration and thus delay the progression of neurodegenerative disease.

\section{Modulation of neuronal function through interaction with signalling pathways}

As mentioned above, flavonoids have been shown to exert neuronal effects through their interactions with a number of protein kinase and lipid kinase signalling cascades, such as the PI3 kinase (PI3K)/Akt, tyrosine kinase, protein kinase $\mathrm{C}$ (PKC) and mitogen-activated protein kinase (MAP kinase) signalling pathways ${ }^{(15,72,119-123)}$ (Fig. 1). Inhibitory or stimulatory actions at these pathways are likely to profoundly affect neuronal function by altering the phosphorylation state of target molecules and/or by modulating gene expression. Although selective inhibitory actions at these kinase cascades may be beneficial in cancer, proliferative diseases, inflammation and neurodegeneration they could be detrimental during development particularly in the immature nervous system where protein and lipid kinase signalling regulates survival, synaptogenesis and neurite outgrowth. In the mature brain, post-mitotic neurones utilise MAP kinase and PI3K cascades in the regulation of key functions such as synaptic plasticity and memory formation ${ }^{(124,125)}$ (Fig. 1), thus flavonoid interactions within these pathways could have unpredictable outcomes and will be dependent both on the cell type and disease studied.

Flavonoids have the potential to bind to the ATP-binding sites of a large number of proteins ${ }^{(126)}$ including, mitochondrial ATPase ${ }^{(127)}$, calcium plasma membrane ATPase ${ }^{(128)}$, protein kinase $\mathrm{A}^{(129)}$, protein kinase $\mathrm{C}^{(122,130-133)}$ and topoisomerase ${ }^{(134)}$. In addition, interactions with the benzodiazepine binding sites of $\mathrm{GABA}_{\mathrm{A}}$ receptors and with adenosine receptors ${ }^{(135,136)}$ have been reported. For example, the stilbene resveratrol and the citrus flavanones, hesperetin and naringenin, have been reported to have inhibitory activity at a number of protein kinases ${ }^{(137-139)}$. This inhibition is mediated via the binding of the polyphenols to the ATP binding site, presumably causing three-dimensional structural changes in the kinase leading to its inactivity. They may also interact directly with mitochondria, for example, by modulating the mitochondrial transition pore (mPT), which controls cytochrome $c$ release during apoptosis ${ }^{(140,141)}$, or by modulating other mitochondrial associated pro-apoptotic factors such as DIABLO/smac ${ }^{(142,143)}$. Potential interactions with the $\mathrm{mPT}$ are especially interesting, as the transition pore possesses a benzodiazepine-binding site where flavonoids may bind ${ }^{(135,136)}$ and influence pore opening and cytochrome $c$ release during apoptosis.

Flavonoids may also be capable of modulating glutamate excitotoxicity via direct scavenging of ROS or by the modulation of calcium influx. Abnormal influx of $\mathrm{Ca}^{2+}$ through AMPA-type glutamate receptors has been strongly implicated in neuronal death associated with a number of brain disorders through activation of $\mathrm{Ca}^{2+}$-dependent proteases, phospholipases and stress-activated kinases. Flavonoids may be capable of rendering heteromeric AMPA receptor assemblies $\mathrm{Ca}^{2+}$-impermeable by up-regulating GluR2 subunit expression $^{(73)}$. Alternatively, flavonoids and their metabolites may prevent neuronal injury by scavenging of reactive intermediates such as superoxide and peroxynitrite derived from calcium mediated activation of xanthine oxidase and nitric oxide synthase, respectively. Lastly, modulation of signalling pathways and inhibition of calcium-activated kinases may also act to prevent excitotoxic death in neurons.

\section{Interactions within the MAP kinase signalling cascade}

Mitogen-activated protein kinases (MAPK) belong to the super-family of serine/threonine kinases and play a central role in transducing various extracellular signals into intracellular responses ${ }^{(144,145)}$. MAPK cascades are organised into three main levels of regulation: (1) a MAP kinase kinase kinase (MAPKKK), which phosphorylates and activates; (2) a MAP kinase kinase (MAPKK), which in turn, phosphorylates and activates; (3) a MAP kinase (MAPK) ${ }^{(144,146)}$ (Fig. 5). The best characterised MAPK pathways are the mitogenic, extracellular signal-regulated protein kinase (ERK) pathway and the stress activated, c-Jun N-terminal kinase (JNK) (Fig. 6) and p38 cascades (Fig. 5). Once activated, ERK, JNK and p38 phosphorylate a number of cytosolic proteins and transcription factors resulting in the enhancement of their transcriptional activities and activation of dependent genes ${ }^{(147)}$.

ERK and JNK are generally considered as having opposing actions, in particular in neuronal apoptosis ${ }^{(148)}$. ERK1/2 are usually associated with pro-survival signalling ${ }^{(149-151)}$ through mechanisms that may involve activation of the cAMP response element binding protein $(\mathrm{CREB})^{(150,152)}$ (Fig. 5), the up-regulation of the anti-apoptotic protein Bcl-2 and non-transcriptional inhibition of $\mathrm{BAD}^{(150,151)}$. On the other hand, JNK has been strongly linked to transcriptiondependent apoptotic signalling ${ }^{(153,154)}$, through the activation of c-Jun ${ }^{(155)}$ and other AP-1 proteins including JunB, JunD and ATF-2 ${ }^{(156)}$ (Fig. 5). Many investigations have indicated that flavonoids and their metabolites may interact selectively within the MAPK signalling pathways ${ }^{(123,157)}$. This modulation of MAPK signalling by flavonoids is significant as ERK1/2 and JNK are involved in growth factor induced mitogenesis, differentiation, apoptosis and various forms of cellular plasticity ${ }^{(153,154,158-160)}$.

Extracellular signal-regulated protein kinase (ERK) pathway. Although most investigations have centred on the potential of flavonoids to modulate the phosphorylation state of ERK $1 / 2^{(15,16,72,161,162)}$, it is likely that their actions on this MAPK isoform result from effects on upstream kinases, such as MEK1 and MEK2 (Fig. 5), and potentially membrane receptors ${ }^{(16)}$. This appears likely as flavonoids have close 

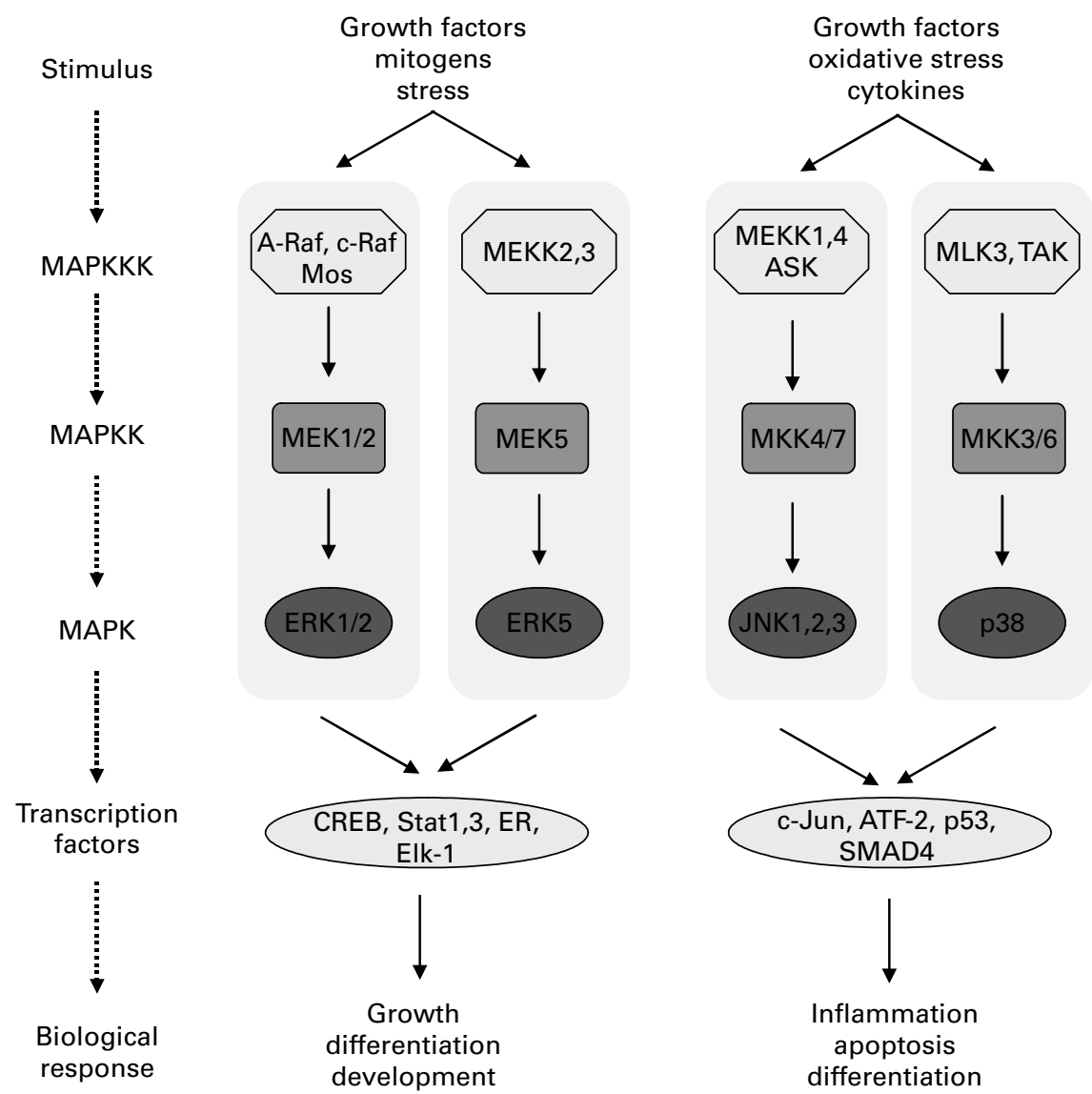

Fig. 5. Potential points of action of flavonoids within MAPK signalling cascades in neurons. Activation of ERK $1 / 2$ or ERK5 are generally pro-survival, whilst inhibitory actions on JNK and p38 pathways are also likely to be neuroprotective.

structural homology to specific inhibitors of ERK signalling, such as PD98059 (2'-amino-3'-methoxyflavone) (Fig. 4). PD98059 is a flavone that has been shown to act in vivo as a highly selective non-competitive inhibitor of MEK1 activation and the MAP kinase cascade ${ }^{(163-166)}$. PD98059 acts via its ability to bind to the inactive forms of MEK so preventing its activation by upstream activators such as c-Raf ${ }^{(165)}$. This raises the possibility that flavonoids, and their metabolites, may also act on this pathway in a similar manner. In support of this, the flavonol quercetin, and to a lesser extent its $O$-methylated metabolites have been shown to induce neuronal apoptosis via a mechanism involving the inhibition of ERK, rather than by induction of pro-apoptotic signalling through $\mathrm{JNK}^{(15)}$. The potent inhibition of ERK activation, and indeed $\mathrm{Akt} / \mathrm{PKB}$ phosphorylation, was also accompanied by downstream activation of $\mathrm{BAD}$ and a subsequent strong activation of caspase- 3 .

On the other hand, some flavonoids have been observed to exert a stimulatory effect on ERK1/2. For example, the flavan-3-ol, (-)-epicatechin, and one of its metabolites, $3^{\prime}$-O-methyl-(-)-epicatechin, have been shown to stimulate phosphorylation of ERK1/2 and the downstream transcription factor CREB at physiologically relevant concentrations ${ }^{(73)}$. Interestingly, this activation of the ERK pathway was no longer apparent at higher concentrations suggesting that effects on this pathway are concentration specific. Furthermore, stimulation of the ERK1/2 and CREB was not observed with (-)-epicatechin-5- $O$ - $\beta$-D-glucuronide suggesting that effects on the ERK pathway may be dependent on cell or membrane permeability, as has been previously reported ${ }^{(28)}$. In support of these observations, the protective action of another flavanol, EGCG, against 6-hydroxy dopamine toxicity and serum deprivation has been shown to involve the restoration of both protein kinase C and ERK1/2 activities ${ }^{(167,168)}$.

One explanation for the concentration-specific regulation of the ERK pathway, and indeed other MAP kinase cascades (JNK and p38), may be related to the ability of flavonoids to exert high affinity receptor agonist-like actions at low concentrations and direct enzyme inhibition at higher concentrations $^{(121,169)}$, or by inducing receptor desensitization. The identity of the primary flavonoid interacting sites in neurons is unknown and could be either at the cell surface or intracellular, although the ERK and PI3K dependence to CREB phosphorylation is reminiscent of ionotropic receptor signalling ${ }^{(170)}$. Receptors reported to act as flavonoid-binding sites, that are present in cortical neurons, are adenosine ${ }^{(171)}$ and $\mathrm{GABA}_{\mathrm{A}}$ receptors ${ }^{(172,173)}$. However, a specific plasma membrane binding site for polyphenols has recently been described in rat brain ${ }^{(174)}$. In addition, monomeric and dimeric flavanols show nanomolar affinity and efficacy at testosterone receptors $^{(175)}$ and resveratrol rapidly activates ERK signalling through alpha and beta oestrogen receptors ${ }^{(176)}$. Collectively, this raises the possibility that flavonoids may act on the ERK pathway via acting through steroid-like receptors in 


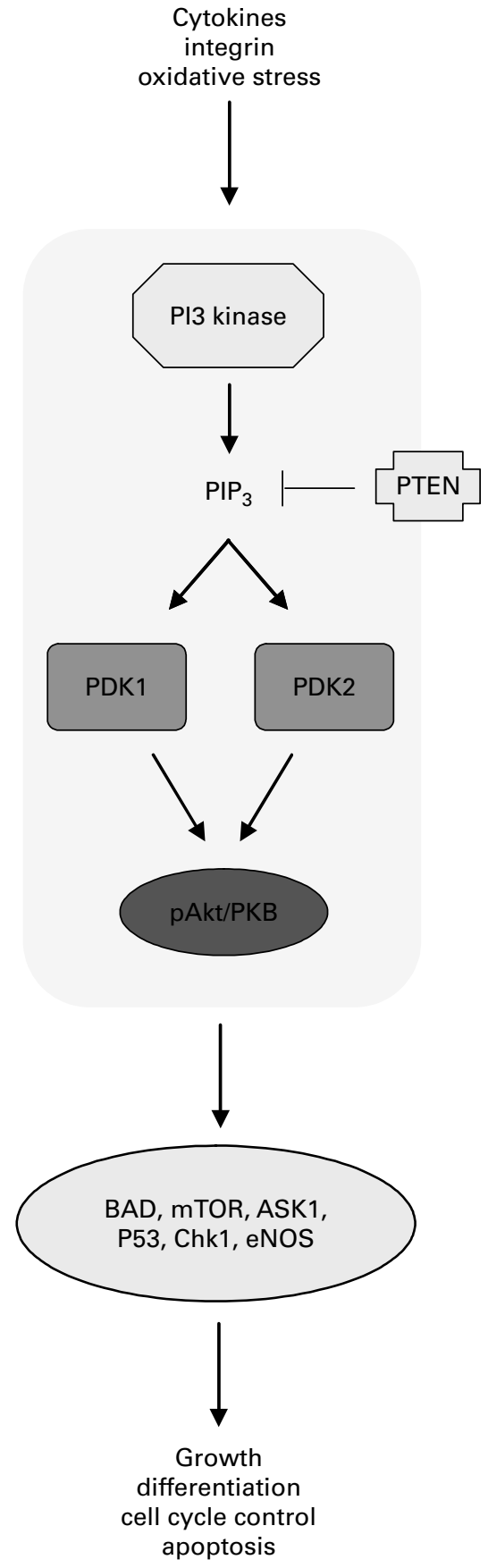

Fig. 6. Potential points of action of flavonoids within PI3K/Akt signalling pathway. Active PI3K catalyzes the production of phosphatidylinositol-3,4,5-triphosphate $\left(\mathrm{PIP}_{3}\right)$ which activates phosphoinositide-dependent protein kinase 1 and 2 (PDK1 and PDK2) and Akt. Through its effects on these kinases, $\mathrm{PI} K \mathrm{~K}$ is involved in the regulation of a wide variety of processes, including cell growth, cell proliferation, differentiation, cell cycle entry, cell migration and apoptosis. Flavonoids have been proposed to act on this pathway via direct modulation of PI3K activity via binding to its ATP binding pocket, in a similar manner to that of LY294002. Alternatively, they may act to modulate the activity of the tumour suppressor, PTEN.

neurons to modulate ERK and CREB-mediated gene expression.

In addition to a receptor-mediated mechanism, it is equally plausibly that changes in ERK activation and related transcription factors (i.e. CREB) may result from flavonoidinduced modulation of phosphatase activity. Phosphatases act in opposition to kinases by de-phosphorylating specific kinases and in the process either activate or de-activate them. Consequently, phosphatases are integral to many signalling pathways. Because ERK and other MAPK require both Thr and Tyr phosphorylation for full activity, dual specificity phosphatases (DSPs) that de-phosphorylate both sites are uniquely positioned to regulate MAPK signal transduction cascades. At least nine DSPs, also termed MAPK phosphatases (MKPs), have been identified in mammalian cells ${ }^{(177)}$. DSPs frequently associated with ERK inactivation include MKP3, MKP4, and phosphatase of activated cells 1 (PAC1), although MKP3 (also termed PYST1) is probably the best studied and the most specific for ERK1/2 versus other MAPK ${ }^{(178)}$. The finding that multiple phosphatases inactivate the ERK pathway suggests that the duration and extent of ERK activation is controlled by a balance of the activities of upstream MAPKK, such as MEK1, and phosphatases, such MKP3. Although there has been intense interest in the ability of flavonoids to modulate kinases, thus far there is no indication that they may affect signalling pathways via a modulation of phosphatase activity. If flavonoids are capable of interacting with phosphatases, such as MKP3, then this is likely to have a dramatic effect on the activation states of important kinases like ERK1/2. Future investigations in this area should consider the potential of flavonoids to inhibit, or activate phosphatases, the concentration-dependency of these effects and the mechanism by which they do so.

Stress-activated protein kinases: c-Jun-N-terminal kinase $(J N K)$ and $p 38$. There is strong evidence linking the activation of JNK to neuronal loss in response to a wide array of pro-apoptotic stimuli in both developmental and degenerative death signalling ${ }^{(153,156,179)}$. The activation of the JNK pathway and the death of specific neuronal populations is crucial during early brain development ${ }^{(180)}$. As with the other MAP kinases, the core signalling unit is composed of a MAPKKK, typically MEKK1-4, which phosphorylate and activate MKK4-7, which then phosphorylate and activate the $\mathrm{JNK}^{(179,181)}$ (Fig. 5). Another MAPKKK, apoptosis signal-regulating kinase 1 (ASK1), also plays an essential role in stressinduced apoptosis ${ }^{(182,183)}$. ASK1 can be activated in response to a variety of stress-related stimuli, including oxidative stress and activates MKK4, which in turn activates JNK (Fig. 5) and indeed $\mathrm{p} 38^{(184)}$. Overexpression of ASK1 has been shown to induce the activation of both JNK and p38 and lead to apoptosis via signals involving the mitochondrial cell death pathway ${ }^{(180,182)}$

Investigation has indicated that oxidative-induced activation of caspase-3 in neurons is blocked by flavonoids, providing compelling evidence in support of a potent anti-apoptotic action of flavonoids in these cells ${ }^{(28,72,185)}$. The flavanols, epicatechin and $3^{\prime}-O$-methyl-epicatechin have been shown to protect neurons against oxidative damage via a mechanism involving the suppression of JNK, and downstream partners, c-Jun and pro-caspase- $3^{(72,186)}$. Similarly, the flavone, baicalein, has been shown to significantly inhibit 6-hydroxydopamine-induced JNK activation and neuronal cell death and quercetin may suppress JNK activity and apoptosis induced by hydrogen peroxide ${ }^{(187,188)}$, 4-hydroxy-2-nonenal ${ }^{(189)}$ and tumour necrosis factor-alpha (TNF-alpha) ${ }^{(157)}$. There are a 
number of potential sites where flavonoids may interact with the JNK pathway. For instance, flavonoid-mediated inhibition of oxidative stress-induced apoptosis may occur by preventing the activation of JNK by influencing one of the many upstream MAPKKK activating proteins that transduce signals to JNK (Fig. 5). For example, their ability to inhibit JNK activation may proceed via flavonoid-induced modulation of the ASK1 phosphorylation state, and its association with 14-3-3 protein, which is essential for suppression of cellular apoptosis $^{(190)}$. Other potential mechanisms include an ability to preserve $\mathrm{Ca}^{2+}$ homeostasis, thereby preventing $\mathrm{Ca}^{2+}$. dependent activation of $\mathrm{JNK}^{(72,179)}$ or an attenuation of the pro-apoptotic signalling cascade lying downstream of JNK.

Another potential site of action may be specific redox-sensitive motifs, notably cysteine residues, similar to those reported for $\mathrm{JNK}^{(191)}$. JNK redox regulation has been proposed to proceed through its binding to redox sensitive proteins such as glutathione- $S$-transferase $(\mathrm{GST})^{(192-194)}$. It has been shown that under unstressed conditions, JNK is associated with GST resulting in the inhibition of JNK activity, but that JNK dissociates from GST following UV or oxidative stress $^{(192,195)}$. Flavonoids also may act to inhibit JNK activity, and possibly other MAPKs, via the nucleophilic addition of flavonoid-o-quinones, formed during the intracellular oxidation of flavonoids ${ }^{(27,196)}$, to cysteine residues on JNK.

\section{PI3 kinase signalling pathway}

In addition to MAPK pathway, flavonoids have been shown to modulate signalling through the serine/threonine kinase, Akt/ $\mathrm{PKB}$, one of the main downstream effectors of PI3K, a pivotal kinase in neuronal survival $^{(197-200)}$ (Fig. 6). Active PI3K catalyzes the production of phosphatidylinositol-3,4,5-triphosphate $\left(\mathrm{PIP}_{3}\right)$ by phosphorylating phosphatidylinositol (PI), phosphatidylinositol-4-phosphate (PIP) and phosphatidylinositol-4,5-bisphosphate (PIP2). PIP 3 may then activate phosphoinositide-dependent protein kinase 1 (PDK1), which plays a central role in many signal transduction pathways ${ }^{(201,202)}$, activating Akt and the PKC isoenzymes p70 S6 kinase and $\mathrm{RSK}^{(203)}$. Through its effects on these kinases, PDK1 is involved in the regulation of a wide variety of processes, including cell growth, cell proliferation, differentiation, cell cycle entry, cell migration and apoptosis ${ }^{(201)}$. One of the most important targets of PI3K and PDK1 is Akt (also known as Protein Kinase B), as this kinase plays a critical role in controlling cellular survival and apoptosis ${ }^{(204-206)}$ (Fig. 6). Akt promotes cell survival by inhibiting apoptosis through its ability to phosphorylate and inactivate several important targets, including $\mathrm{Bad}^{(207)}$, Forkhead transcription factors ${ }^{(208,209)}$ and caspase-9 ${ }^{(205)}$. Indeed, activation of Akt/ PKB in neurons has been shown to lead to an inhibition of proteins central to neuronal death machinery, such as the pro-apoptotic $\mathrm{Bcl}-2$ family member, $\mathrm{Bad}^{(210)}$, and members of the caspase family ${ }^{(150,197)}$ that specifically cleave poly(ADP-ribose) polymerase ${ }^{(197,198)}$, thus promoting cell survival. Akt is activated by phospholipid binding and activation loop phosphorylation at $\mathrm{Thr}^{308}$ by PDK $1^{(211)}$ and by phosphorylation within the carboxy terminus at $\mathrm{Ser}^{473}$ and the activation of Akt is a pro-survival event in many cell types due to its ability to inactivate Bad via phosphorylation at $\operatorname{Ser}^{136(212,213)}$.
There is good evidence that flavonoids inhibit PI3K via direct interactions with its ATP binding site. Indeed, a number of studies have demonstrated that the structure of flavonoids determines whether or not they act as potent inhibitors of $\mathrm{PI} 3 \mathrm{~K}^{(121,214)}$. One of the most selective PI3K inhibitors available, LY294002 (Fig. 4), was modelled on the structure of quercetin $^{(119,120)}$. LY294002 and quercetin fit into the ATP binding pocket of the enzyme although with surprisingly different orientations ${ }^{(169)}$. It appears that the number and substitution of hydroxyl groups on the B-ring and the degree of un-saturation of the $\mathrm{C} 2-\mathrm{C} 3$ bond are important determinants of this particular bioactivity. Interestingly in this regard quercetin and some of its in vivo metabolites inhibit pro-survival Akt/PKB signalling pathways ${ }^{(15)}$ by a mechanism of action consistent with quercetin and its metabolites acting at and inhibiting PI3K activity. Prior to inducing measurable losses of neuronal viability, quercetin stimulates a strong inhibition of basal Akt phosphorylation at both the regulatory serine ${ }^{473}$ and catalytic threonine ${ }^{308}$ sites, rendering it inactive. The inhibition of Akt/ PKB phosphorylation in this way may reflect potential inhibition of its upstream partner PI3K, as has previously been described $^{(119)}$. If Akt/PKB inhibition is sustained, which has been reported to occur during neuronal exposure to quercetin, this leads to extensive caspase- 3 activation and subsequent caspase-dependent cleavage of Akt/PKB, an event that effectively 'switches off' a major survival signal and results in the acceleration of apoptotic death ${ }^{(15)}$. However, at lower concentrations, quercetin has also been shown to trigger CREB activation in neurons indicating that exposure concentration is pivotal in determining either pro-apoptotic or anti-apoptotic effects $^{(15)}$. Indeed, low concentrations of quercetin, may activate the MAPK pathway (ERK2, JNK1 and p38) leading to expression of survival genes (c-Fos, c-Jun) and defensive genes (Phase II detoxifying enzymes; glutathione- $S$-transferase, quinone reductase) resulting in survival and protective mechanisms (homeostasis response), whereas high concentrations stimulate pro-apoptotic pathways and caspase activation ${ }^{(123)}$.

Another potential mechanism by which flavonoids may modulate the PI3 kinase/Akt signalling pathway is by their ability to modulate the expression or activity of PTEN (phosphatase and tensin homologue deleted on chromosome ten), also referred to as MMAC (mutated in multiple advanced cancers) phosphatase ${ }^{(215-217)}$. PTEN is a tumour suppressor implicated in a wide variety of human cancers ${ }^{(218)}$ and the main substrates of PTEN are inositol phospholipids generated by the activation of the PI $3 \mathrm{~K}^{(219)}$. PTEN acts a major negative regulator of the PI3K/Akt signalling pathway ${ }^{(218,220)}$ and thus a modulation of its expression or activation by flavonoids will have a profound effect of cellular function (Fig. 6). For example, if flavonoids are capable of inhibiting PTEN in cancer cells this may lead to an increase in cancer cell proliferation and tumour growth. On the other hand, its activation in post-mitotic cells, such as neurons, may have a positive effect by increasing Akt and CREB activity leading to a promotion of neuronal survival and synaptic plasticity (Fig. 2).

\section{The Nrf-Keapl/ARE pathway and interactions with MAP kinase and PI3 kinase}

The regulation of $\gamma$-GCS and other detoxification proteins, such as glutathione peroxidase, has been shown to involve 
the transcription factor NF-E2-related factor $2, \mathrm{Nrf}^{(221,222)}$ and $\mathrm{Nrf1}^{(223,224)}$. Nrf2 is known to regulate the gene expression of phase II detoxification enzymes and antioxidant proteins through an enhancer sequence referred to as the 'electrophile responsive element' or 'antioxidant responsive element' (EpRE/ARE) ${ }^{(225,226)}$. Deficiencies in Nrf1 and Nrf2 have been found to largely abolish the constitutive and/or inducible expression of defence enzyme genes in response to oxidative and xenobiotic stress ${ }^{(227,228)}$. Recent reports have suggested that signalling through Nrf2 is involved in HO-1 induction by polyphenols such as epigallocatechin-3-gallate ${ }^{(229)}$, whilst sulforaphane and curcumin have been shown to exert anti-inflammatory and anti-carcinogenic effects through activation of $\mathrm{Nrf} 2$ and subsequent up-regulation of gastrointestinal $\mathrm{GPx}^{(230)}$. The protective effects of the isoflavone, genistein has also been shown to depend primarily on the activation of glutathione peroxidase mediated by Nrf1 activation $^{(231)}$. However, there is limited information regarding the effects of flavonoids on Nrf1 and Nrf2 activation or whether their ability to modulate this important signalling pathway mediates their cellular beneficial effects.

The actin-binding protein, Keap1, has been identified as a docking site for Nrf2 that is responsible for sequestering Nrf2 in the cytoplasmic compartment of unstressed cells ${ }^{(232)}$. The association between the two proteins is between the C-terminal DGR domain of Keap1 and the N-terminal Neh2 domain of Nrf2. Although the exact mechanism of cytosolic sequestration of Nrf1 is unknown, it is also known to contain a Neh2 domain, and therefore it too may interact with Keap1 in vivo ${ }^{(233)}$. One way in which flavnoids may induce Nrf1 and Nrf2 are via the rapid but non-toxic increases in intracellular oxidative species as has been suggested for $3^{\prime}, 4^{\prime}, 5^{\prime}, 3,4,5$-hexamethoxy-chalcone ${ }^{(234)}$. Increases in reactive oxygen species may induce the disruption of the Keap1/Nrf2 complex through oxidation of $\mathrm{Cys}_{273}$ and $\mathrm{Cys}_{288}$ residues on Keap1. Cellular uptake and metabolism of flavonoids has been shown to lead to the formation of intracellular flavonoid-o-quinone species ${ }^{(27,196,231)}$, which increase intracellular oxidative stress, or alternatively may react directly with $\mathrm{Cys}_{273}$ and $\mathrm{Cys}_{288}$ and/or other cysteine residues located on Keap1 ${ }^{(226,235)}$. Interactions with cysteinyl residues would be expected to trigger the release Nrf1/Nrf2 from Keap1, so allowing their phosphorylation and translocation to the nucleus, where they may interact with the electrophile response element. Future studies are required to determine the precise nature of interactions between intracellular flavonoid metabolites, such as $o$-quinones, and the Keap1/Nrf1 complex.

Besides the direct oxidation or covalent modification of thiol groups of Keap1, the Nrf2-Keap1-ARE signalling can be modulated by post-transcriptional modification of Nrf2. Three major signal transduction pathways have been implicated in the regulation of ARE/EpRE motifs and nuclear translocation of Nrf2. These are the MAPK cascade, protein kinase C (PKC) and PI3 kinase ${ }^{(236-238)}$ (Fig. 7). For example, the activation of ERK and JNK has been shown to induce ARE-mediated gene expression via the recruitment of a co-activator to the transcription initiation complex and an increase in Nrf2 transcriptional activity, whereas, p38 had the opposite effect ${ }^{(239,240)}$. Furthermore, PI3 kinase also

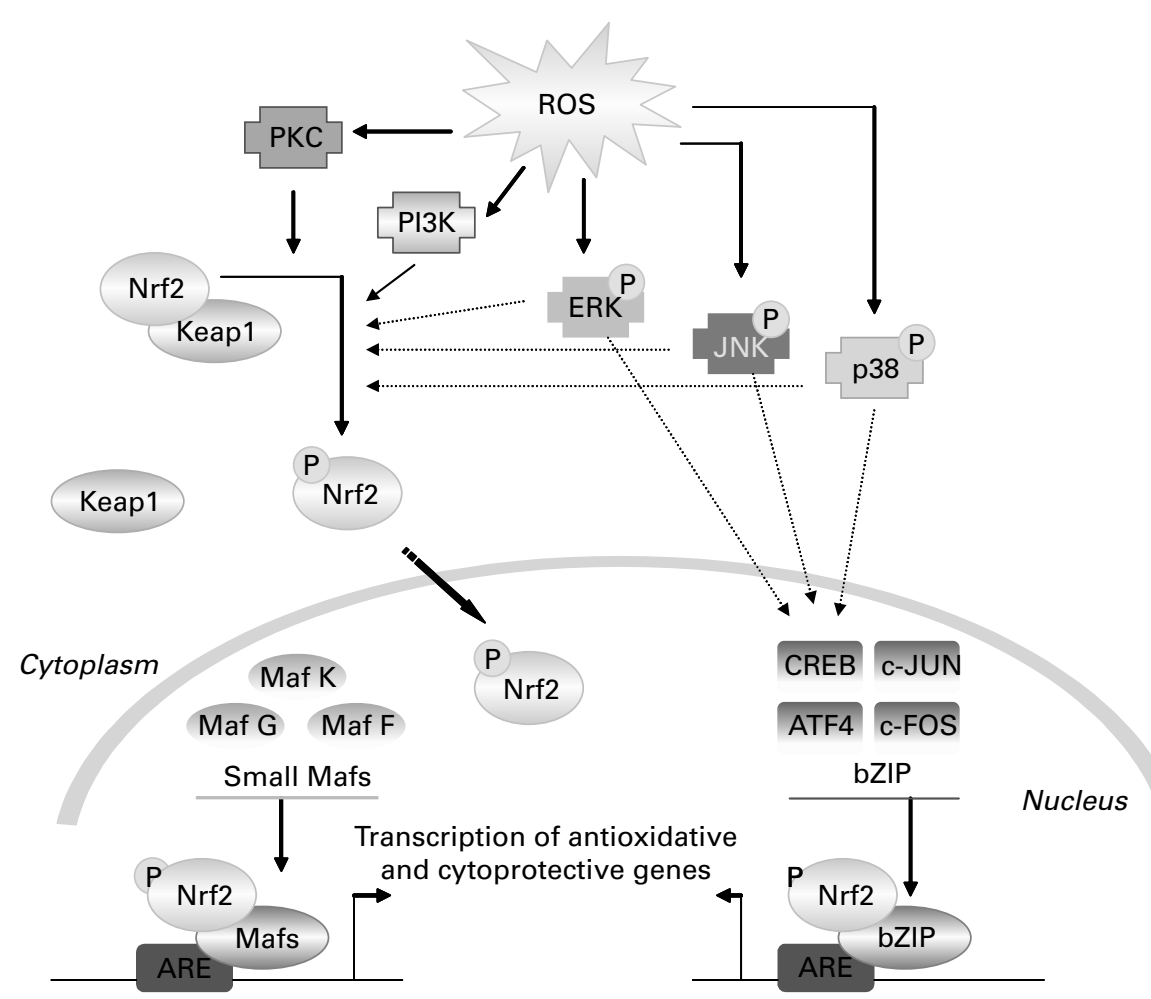

Fig. 7. Involvement of MAP kinase and PI3 kinase signalling in regulation of the Keap1-Nrf2 pathway. Inactive Nrf2 is retained in the cytosol by association a complex with the cytoskeletal protein Keap1. Cytosolic Nrf2 may be phosphorylated in response to MAP kinase, PI3 kinase and protein kinase C pathways. Following phosphorylation, Nrf2 translocates to the nucleus, where it activates gene expression through binding to the ARE, following its interaction with other transcription factors in the bZIP family (CREB, ATF-4 and fos or c-Jun). Nrf2 activation of genes is opposed by small maf proteins, including MafG and MafK, maintaining a counterbalance to Nrf2 and balancing the oxidation level of the intracellular environment. 
appears to be involved in Nrf2 activation in cells exposed to peroxynitrite $^{(241)}$ and hemin ${ }^{(242)}$. In response to oxidative stress, the activation of signalling cascades mediated by PI3K results in de-polymerization of actin microfilaments thereby facilitating Nrf2 translocation to the nucleus ${ }^{(241)}$. As flavonoids are known to modulate MAP kinase and PI3 kinase/Akt pathways (outlined above), it is highly likely that they will also affect the activation and nuclear translocation of Nrf1 and/or Nrf2 indirectly through the modulation of these upstream pathways (Fig. 7).

\section{Conclusions}

Evidence suggests that dietary phytochemicals, in particular flavonoids, may exert beneficial effects in the CNS by protecting neurons against stress induced injury, by suppressing the activation of microglia and astrocytes, which mediate neuroinflammation, and by promoting synaptic plasticity, memory and cognitive function. Evidence also supports the localization of flavonoids within the brain, thus these phytochemicals may be regarded as a potential neuroprotective, neuromodulatory or anti-neuroinflammatory agents. It appears highly likely that such beneficial properties are mediated by their abilities to interact with both protein and lipid kinase signalling cascades, rather then via their potential to act as classical antioxidants. The concentrations of flavonoids encountered in vivo are sufficiently high to exert pharmacological activity at receptors, kinases and transcription factors. Presently the precise sites of action are unknown, although it is likely that their activity depends on their ability to (1) bind to ATP sites on enzymes and receptors; (2) modulate the activity of kinases directly, i.e. MAPKKK, MAPKK or MAPK; (3) affect the function of important phosphatases, which act in opposition to kinases; (4) preserve $\mathrm{Ca}^{2+}$ homeostasis, thereby preventing $\mathrm{Ca}^{2+}$ dependent activation of kinases in neurons; and (5) modulate signalling cascades lying downstream of kinases, i.e. transcription factor activation and binding to promoter sequences.

However, at present, more information is required in order to understand the precise cellular site(s) of action of flavonoids. For instance, it is still unclear whether flavonoid action requires cellular uptake or if they are capable of mediating effects via extracellular receptor binding. Presently, there is no certainty either way, although flavonoid glucuronides, which are unable to enter cells to any significant degree, do not appear to express cellular effects. This may suggest a requirement for cytosolic localisation, although it could equally signify that the conjugation of flavonoids with glucuronide or sulphate moieties blocks receptor binding and therefore their cellular activity. It seems likely that the inhibition of Akt is almost certainly mediated via actions at $\mathrm{PI} 3 \mathrm{~K}$, thus requiring cellular uptake. However, actions at ERK1/2 could result from either flavonoid modulation of upstream regulatory kinases or by binding directly to receptors. The challenge now is to determine the precise site(s) of action of flavonoids within the signalling pathways and the sequence of events that allow them to regulate neuronal function in the central nervous system.

Ultimately actions within these neuronal signalling cascades may be beneficial or negative in the context of the brain. For example, whilst they may be positive in the treatment of proliferative diseases, they could be detrimental to the nervous system, at least at high concentrations, where these same pathways act to control neuronal survival and synaptic plasticity. Thus, flavonoid interactions with intracellular signalling pathways could have unpredictable outcomes and will be dependent on the cell type (i.e. neurons, astrocytes, microglia, oligodendrocytes), the disease studied and the stimulus applied. In summary, it is evident that flavonoids are potent bioactive molecules and a clear understanding of their mechanisms of action as modulators of cell signalling will be crucial in the evaluation of their potential to act as inhibitors of neurodegeneration or as modulators of brain function.

\section{Acknowledgements}

The author is sponsored by the Biotechnology and Biological Sciences Research Council (BB/C518222/1 and BB/F008953/1) and the Medical Research Council (G0400278/NI02). The publication of this paper was made possible by the financial support of the European Co-operation in the field of Scientific and Technical (COST) Research Action 926 'Impact of new technologies on the health benefits and safety of bioactive plant compounds' (2004-2008). The author had no conflicts of interest to disclose.

\section{References}

1. Youdim KA \& Joseph JA (2001) A possible emerging role of phytochemicals in improving age-related neurological dysfunctions: a multiplicity of effects. Free Radic Biol Med 30, 583-594.

2. Youdim KA, Spencer JP, Schroeter H \& Rice-Evans C (2002) Dietary flavonoids as potential neuroprotectants. Biol Chem 383, 503-519.

3. Galli RL, Shukitt-Hale B, Youdim KA \& Joseph JA (2002) Fruit polyphenolics and brain aging: nutritional interventions targeting age-related neuronal and behavioral deficits. Ann NY Acad Sci 959, 128-132.

4. Unno K, Takabayashi F, Kishido T \& Oku N (2004) Suppressive effect of green tea catechins on morphologic and functional regression of the brain in aged mice with accelerated senescence (SAMP10). Exp Gerontol 39, 1027-1034.

5. Haque AM, Hashimoto M, Katakura M, Tanabe Y, Hara Y \& Shido O (2006) Long-term administration of green tea catechins improves spatial cognition learning ability in rats. J Nutr 136, 1043-1047.

6. Kuriyama S, Hozawa A, Ohmori K, Shimazu T, Matsui T, Ebihara S, Awata S, Nagatomi R, Arai H \& Tsuji I (2006) Green tea consumption and cognitive function: a cross-sectional study from the Tsurugaya Project 1. Am J Clin Nutr 83, 355-361.

7. Wang Y, Wang L, Wu J \& Cai J (2006) The in vivo synaptic plasticity mechanism of EGb 761-induced enhancement of spatial learning and memory in aged rats. $\mathrm{Br} J$ Pharmacol 148, $147-153$.

8. Inanami O, Watanabe $\mathrm{Y}$, Syuto B, Nakano M, Tsuji M \& Kuwabara M (1998) Oral administration of (-)catechin protects against ischemia-reperfusion-induced neuronal death in the gerbil. Free Radic Res 29, 359-365.

9. Luo Y, Smith JV, Paramasivam V, Burdick A, Curry KJ, Buford JP, Khan I, Netzer WJ, Xu H \& Butko P (2002) Inhibition of amyloid-beta aggregation and caspase-3 activation by the Ginkgo biloba extract EGb761. Proc Natl Acad Sci U S A 99, 12197-12202. 
10. Bastianetto S, Zheng WH \& Quirion R (2000) The Ginkgo biloba extract (EGb 761) protects and rescues hippocampal cells against nitric oxide-induced toxicity: involvement of its flavonoid constituents and protein kinase C. J Neurochem 74, $2268-2277$

11. Zimmermann M, Colciaghi F, Cattabeni F \& Di Luca M (2002) Ginkgo biloba extract: from molecular mechanisms to the treatment of Alzhelmer's disease. Cell Mol Biol (Noisy-le-grand) 48, 613-623.

12. Datla KP, Christidou M, Widmer WW, Rooprai HK \& Dexter DT (2001) Tissue distribution and neuroprotective effects of citrus flavonoid tangeretin in a rat model of Parkinson's disease. Neuroreport 12, 3871-3875.

13. Rice-Evans CA, Miller NJ \& Paganga G (1996) Structureantioxidant activity relationships of flavonoids and phenolic acids. Free Radic Biol Med 20, 933-956.

14. Williams RJ, Spencer JPE \& Rice-Evans C (2004) Flavonoids: antioxidants or signalling molecules? Free Radic Biol Med 36, $838-849$.

15. Spencer JPE, Rice-Evans C \& Williams RJ (2003) Modulation of pro-survival Akt/PKB and ERK1/2 signalling cascades by quercetin and its in vivo metabolites underlie their action on neuronal viability. J Biol Chem 278, 34783-34793.

16. Schroeter H, Boyd C, Spencer JPE, Williams RJ, Cadenas E \& Rice-Evans C (2002) MAPK signaling in neurodegeneration: influences of flavonoids and of nitric oxide. Neurobiol Aging 23, $861-880$.

17. Manach C, Scalbert A, Morand C, Remesy C \& Jimenez L (2004) Polyphenols: food sources and bioavailability. Am J Clin Nutr 79, 727-747.

18. Rice-Evans C (2001) Flavonoid antioxidants. Curr Med Chem 8, 797-807.

19. Rice-Evans C (1995) Plant polyphenols: free radical scavengers or chain-breaking antioxidants? Biochem Soc Symp 61, 103-116.

20. Spencer JPE, Schroeter H, Rechner AR \& Rice-Evans C (2001) Bioavailability of flavan-3-ols and procyanidins: gastrointestinal tract influences and their relevance to bioactive forms in vivo. Antioxid Redox Signal 3, 1023-1039.

21. Spencer JPE, Srai SK \& Rice-Evans C (2003) Metabolism in the small intestine and gastrointestinal tract. In Flavonoids in Health and Disease, pp. 363-390 [C Rice-Evans and L Packer, editors]. New York: Marcel Dekker.

22. Walle $\mathrm{T}$, Walgren RA, Walle UK, Galijatovic A \& Vaidyanathan JB (2003) Understanding the bioavailability of flavanoids through studies in Caco-2 cells. In Flavonoids in Health and Disease, pp. 349-362 [C Rice-Evans and L Packer, editors]. New York: Marcel Dekker.

23. Day AJ \& Williamson G (2003) Absorption of quercetin glycosides. In Flavonoids in Health and Disease, pp. 391-412 [C Rice-Evans and L Packer, editors]. New York: Marcel Dekker.

24. Donovan JL \& Waterhouse AL (2003) Bioavailability of flavanol monomers. In Flavonoids in Health and Disease, pp. 413-440 [C Rice-Evans and L Packer, editors]. New York: Marcel Dekker.

25. Spencer JPE, Chowrimootoo G, Choudhury R, Debnam ES, Srai SK \& Rice-Evans C (1999) The small intestine can both absorb and glucuronidate luminal flavonoids. FEBS Lett $\mathbf{4 5 8}$, 224-230.

26. Scheline RR (1999) Metabolism of oxygen heterocyclic compounds. In CRC Handbook of Mammalian Metabolism of Plant Compounds, pp. 243-295 Boca Ranton: CRC Press.

27. Spencer JPE, Kuhnle GG, Williams RJ \& Rice-Evans C (2003) Intracellular metabolism and bioactivity of quercetin and its in vivo metabolites. Biochem J 372, 173-181.
28. Spencer JPE, Schroeter H, Crossthwaithe AJ, Kuhnle G, Williams RJ \& Rice-Evans C (2001) Contrasting influences of glucuronidation and O-methylation of epicatechin on hydrogen peroxide-induced cell death in neurons and fibroblasts. Free Radic Biol Med 31, 1139-1146.

29. Miyake Y, Shimoi K, Kumazawa S, Yamamoto K, Kinae N \& Osawa T (2000) Identification and antioxidant activity of flavonoid metabolites in plasma and urine of eriocitrin-treated rats. J Agric Food Chem 48, 3217-3224.

30. Terao J, Yamaguchi S, Shirai M, Miyoshi M, Moon JH, Oshima S, Inakuma T, Tsushida T \& Kato Y (2001) Protection by quercetin and quercetin 3-O-beta-D-glucuronide of peroxynitrite-induced antioxidant consumption in human plasma low-density lipoprotein. Free Radic Res 35, 925-931.

31. Shirai M, Moon JH, Tsushida T \& Terao J (2001) Inhibitory effect of a quercetin metabolite, quercetin 3-O-beta-D-glucuronide, on lipid peroxidation in liposomal membranes. J Agric Food Chem 49, 5602-5608.

32. Yamamoto N, Moon JH, Tsushida T, Nagao A \& Terao J (1999) Inhibitory effect of quercetin metabolites and their related derivatives on copper ion-induced lipid peroxidation in human low-density lipoprotein. Arch Biochem Biophys 372, 347-354.

33. da Silva EL, Piskula MK, Yamamoto N, Moon JH \& Terao J (1998) Quercetin metabolites inhibit copper ion-induced lipid peroxidation in rat plasma. FEBS Lett 430, 405-408.

34. Abbott NJ (2002) Astrocyte-endothelial interactions and blood-brain barrier permeability. J Anat 200, 629-638.

35. Youdim KA, Dobbie MS, Kuhnle G, Proteggente AR, Abbott NJ \& Rice-Evans C (2003) Interaction between flavonoids and the blood-brain barrier: in vitro studies. $J$ Neurochem $\mathbf{8 5}$ 180-192.

36. Youdim KA, Shukitt-Hale B \& Joseph JA (2004) Flavonoids and the brain: interactions at the blood-brain barrier and their physiological effects on the central nervous system. Free Radic Biol Med 37, 1683-1693.

37. Youdim KA, Qaiser MZ, Begley DJ, Rice-Evans CA \& Abbott NJ (2004) Flavonoid permeability across an in situ model of the blood-brain barrier. Free Radic Biol Med 36, 592-604.

38. Aasmundstad TA, Morland J \& Paulsen RE (1995) Distribution of morphine 6-glucuronide and morphine across the blood-brain barrier in awake, freely moving rats investigated by in vivo microdialysis sampling. J Pharmacol Exp Ther 275, 435-441.

39. Sperker B, Backman JT \& Kroemer HK (1997) The role of beta-glucuronidase in drug disposition and drug targeting in humans. Clin Pharmacokinet 33, 18-31.

40. Kroemer HK \& Klotz U (1992) Glucuronidation of drugs. A re-evaluation of the pharmacological significance of the conjugates and modulating factors. Clin Pharmacokinet 23, $292-310$.

41. Lin JH \& Yamazaki M (2003) Role of P-glycoprotein in pharmacokinetics: clinical implications. Clin Pharmacokinet 42, $59-98$.

42. Suganuma $M$, Okabe $S$, Oniyama $M$, Tada $Y$, Ito $H$ \& Fujiki $H$ (1998) Wide distribution of $[3 \mathrm{H}](-)$-epigallocatechin gallate, a cancer preventive tea polyphenol, in mouse tissue. Carcinogenesis 19, 1771-1776.

43. Abd El Mohsen MM, Kuhnle G, Rechner AR, Schroeter H, Rose S, Jenner P \& Rice-Evans CA (2002) Uptake and metabolism of epicatechin and its access to the brain after oral ingestion. Free Radic Biol Med 33, 1693-1702.

44. Talavera S, Felgines C, Texier O, Besson C, Gil-Izquierdo A, Lamaison JL \& Remesy C (2005) Anthocyanin metabolism in rats and their distribution to digestive area, kidney, and brain. J Agric Food Chem 53, 3902-3908. 
45. El Mohsen MA, Marks J, Kuhnle G, Moore K, Debnam E, Kaila SS, Rice-Evans C \& Spencer JP (2006) Absorption, tissue distribution and excretion of pelargonidin and its metabolites following oral administration to rats. $\mathrm{Br} \mathrm{J} \mathrm{Nutr}$ 95, $51-58$.

46. Andres-Lacueva C, Shukitt-Hale B, Galli RL, Jauregui O, Lamuela-Raventos RM \& Joseph JA (2005) Anthocyanins in aged blueberry-fed rats are found centrally and may enhance memory. Nutr Neurosci 8, 111-120.

47. Halliwell B, Zhao K \& Whiteman M (2000) The gastrointestinal tract: a major site of antioxidant action? Free Radic Res $\mathbf{3 3}$, 819-830.

48. Joseph JA, Shukitt-Hale B, Denisova NA, Prior RL, Cao G, Martin A, Taglialatela G \& Bickford PC (1998) Long-term dietary strawberry, spinach, or vitamin E supplementation retards the onset of age-related neuronal signal-transduction and cognitive behavioral deficits. $J$ Neurosci 18, 8047-8055.

49. Joseph JA, Shukitt-Hale B, Denisova NA, Bielinski D, Martin A, McEwen JJ \& Bickford PC (1999) Reversals of age-related declines in neuronal signal transduction, cognitive, and motor behavioral deficits with blueberry, spinach, or strawberry dietary supplementation. J Neurosci 19, 8114-8121.

50. Casadesus G, Shukitt-Hale B, Stellwagen HM, Zhu X, Lee HG, Smith MA \& Joseph JA (2004) Modulation of hippocampal plasticity and cognitive behavior by short-term blueberry supplementation in aged rats. Nutr Neurosci $\mathbf{7}$, 309-316.

51. Shukitt-Hale B, Smith DE, Meydani M \& Joseph JA (1999) The effects of dietary antioxidants on psychomotor performance in aged mice. Exp Gerontol 34, 797-808.

52. Joseph JA, Shukitt-Hale B \& Casadesus G (2005) Reversing the deleterious effects of aging on neuronal communication and behavior: beneficial properties of fruit polyphenolic compounds. Am J Clin Nutr 81, 313S-316S.

53. Goyarzu P, Malin DH, Lau FC, et al. (2004) Blueberry supplemented diet: effects on object recognition memory and nuclear factor-kappa B levels in aged rats. Nutr Neurosci 7, $75-83$.

54. Joseph JA, Denisova NA, Arendash G, Gordon M, Diamond D, Shukitt-Hale B \& Morgan D (2003) Blueberry supplementation enhances signaling and prevents behavioral deficits in an Alzheimer disease model. Nutr Neurosci 6, 153-162.

55. Ramirez MR, Izquierdo I, do Carmo Bassols RM, Zuanazzi JA, Barros D \& Henriques AT (2005) Effect of lyophilised Vaccinium berries on memory, anxiety and locomotion in adult rats. Pharmacol Res 52, 457-462.

56. Schroeter H, Heiss C, Balzer J, Kleinbongard P, Keen CL, Hollenberg NK, Sies H, Kwik-Uribe C, Schmitz HH \& Kelm M (2006) (-)-Epicatechin mediates beneficial effects of flavanol-rich cocoa on vascular function in humans. Proc Natl Acad Sci U S A 103, 1024-1029.

57. Francis ST, Head K, Morris PG \& Macdonald IA (2006) The effect of flavanol-rich cocoa on the fMRI response to a cognitive task in healthy young people. J Cardiovasc Pharmacol 47, Suppl. 2, S215-S220.

58. Fisher ND, Sorond FA \& Hollenberg NK (2006) Cocoa flavanols and brain perfusion. J Cardiovasc Pharmacol 47, Suppl. 2, S210-S214.

59. Gage FH (2000) Mammalian neural stem cells. Science 287, $1433-1438$

60. Palmer TD, Willhoite AR \& Gage FH (2000) Vascular niche for adult hippocampal neurogenesis. J Comp Neurol 425, 479-494.

61. Harris KM \& Kater SB (1994) Dendritic spines: cellular specializations imparting both stability and flexibility to synaptic function. Annu Rev Neurosci 17, 341-371.
62. Carew TJ (1996) Molecular enhancement of memory formation. Neuron 16, 5-8.

63. Martin KC, Barad M \& Kandel ER (2000) Local protein synthesis and its role in synapse-specific plasticity. Curr Opin Neurobiol 10, 587-592.

64. Kelleher RJ III, Govindarajan A \& Tonegawa S (2004) Translational regulatory mechanisms in persistent forms of synaptic plasticity. Neuron 44, 59-73.

65. Impey S, McCorkle SR, Cha-Molstad H, Dwyer JM, Yochum GS, Boss JM, McWeeney S, Dunn JJ, Mandel G \& Goodman RH (2004) Defining the CREB regulon: a genome-wide analysis of transcription factor regulatory regions. Cell 119, $1041-1054$

66. Barco A, Bailey CH \& Kandel ER (2006) Common molecular mechanisms in explicit and implicit memory. J Neurochem $\mathbf{9 7 ,}$ $1520-1533$.

67. Bourtchuladze R, Frenguelli B, Blendy J, Cioffi D, Schutz G \& Silva AJ (1994) Deficient long-term memory in mice with a targeted mutation of the cAMP-responsive element-binding protein. Cell 79, 59-68.

68. Tully T, Bourtchouladze R, Scott R \& Tallman J (2003) Targeting the CREB pathway for memory enhancers. Nat Rev Drug Discov 2, 267-277.

69. Pham TA, Impey S, Storm DR \& Stryker MP (1999) CREmediated gene transcription in neocortical neuronal plasticity during the developmental critical period. Neuron 22, 63-72.

70. Impey S, Smith DM, Obrietan K, Donahue R, Wade C \& Storm DR (1998) Stimulation of cAMP response element (CRE)-mediated transcription during contextual learning. Nat Neurosci 1, 595-601.

71. Impey S, Mark M, Villacres EC, Poser S, Chavkin C \& Storm DR (1996) Induction of CRE-mediated gene expression by stimuli that generate long-lasting LTP in area CA1 of the hippocampus. Neuron 16, 973-982.

72. Schroeter H, Spencer JP, Rice-Evans C \& Williams RJ (2001) Flavonoids protect neurons from oxidized low-density-lipoprotein-induced apoptosis involving c-Jun $\mathrm{N}$-terminal kinase (JNK), c-Jun and caspase-3. Biochem J 358, 547-557.

73. Schroeter H, Bahia P, Spencer JPE, Sheppard O, Rattray M, Rice-Evans C \& Williams RJ (2007) (-)-Epicatechin stimulates ERK-dependent cyclic AMP response element activity and upregulates GLUR2 in cortical neurons $J$ Neurochem 101, 1596-1606.

74. Maher P, Akaishi T \& Abe K (2006) Flavonoid fisetin promotes ERK-dependent long-term potentiation and enhances memory. Proc Natl Acad Sci U S A 103, 16568-16573.

75. Conkright MD, Guzman E, Flechner L, Su AI, Hogenesch JB \& Montminy M (2003) Genome-wide analysis of CREB target genes reveals a core promoter requirement for cAMP responsiveness. Mol Cell 11, 1101-1108.

76. Tao X, Finkbeiner S, Arnold DB, Shaywitz AJ \& Greenberg $\mathrm{ME}$ (1998) $\mathrm{Ca}^{2+}$ influx regulates BDNF transcription by a CREB family transcription factor-dependent mechanism. Neuron 20, 709-726.

77. Shieh PB, Hu SC, Bobb K, Timmusk T \& Ghosh A (1998) Identification of a signaling pathway involved in calcium regulation of BDNF expression. Neuron 20, 727-740.

78. Bramham CR \& Messaoudi E (2005) BDNF function in adult synaptic plasticity: the synaptic consolidation hypothesis. Prog Neurobiol 76, 99-125.

79. Patterson SL, Grover LM, Schwartzkroin PA \& Bothwell M (1992) Neurotrophin expression in rat hippocampal slices: a stimulus paradigm inducing LTP in CA1 evokes increases in BDNF and NT-3 mRNAs. Neuron 9, 1081-1088.

80. Thomas K \& Davies A (2005) Neurotrophins: a ticket to ride for BDNF. Curr Biol 15, R262-R264. 
81. Peng S, Wuu J, Mufson EJ \& Fahnestock M (2005) Precursor form of brain-derived neurotrophic factor and mature brainderived neurotrophic factor are decreased in the pre-clinical stages of Alzheimer's disease. J Neurochem 93, 1412-1421.

82. Michalski B \& Fahnestock M (2003) Pro-brain-derived neurotrophic factor is decreased in parietal cortex in Alzheimer's disease. Brain Res Mol Brain Res 111, 148-154.

83. Egan MF, Kojima M, Callicott JH, et al. (2003) The BDNF val66met polymorphism affects activity-dependent secretion of BDNF and human memory and hippocampal function. Cell 112, 257-269.

84. Linnarsson S, Bjorklund A \& Ernfors P (1997) Learning deficit in BDNF mutant mice. Eur J Neurosci 9, 2581-2587.

85. Mu JS, Li WP, Yao ZB \& Zhou XF (1999) Deprivation of endogenous brain-derived neurotrophic factor results in impairment of spatial learning and memory in adult rats. Brain Res 835, 259-265.

86. Minichiello L, Korte M, Wolfer D, Kuhn R, Unsicker K, Cestari V, Rossi-Arnaud C, Lipp HP, Bonhoeffer T \& Klein R (1999) Essential role for TrkB receptors in hippocampus-mediated learning. Neuron 24, 401-414.

87. Wullschleger S, Loewith R \& Hall MN (2006) TOR signaling in growth and metabolism. Cell 124, 471-484.

88. Schratt GM, Nigh EA, Chen WG, Hu L \& Greenberg ME (2004) BDNF regulates the translation of a select group of mRNAs by a mammalian target of rapamycin-phosphatidylinositol 3-kinase-dependent pathway during neuronal development. J Neurosci 24, 7366-7377.

89. Yin Y, Edelman GM \& Vanderklish PW (2002) The brainderived neurotrophic factor enhances synthesis of Arc in synaptoneurosomes. Proc Natl Acad Sci U S A 99, 2368-2373.

90. Waltereit R, Dammermann B, Wulff P, Scafidi J, Staubli U, Kauselmann G, Bundman M \& Kuhl D (2001) Arg3.1/Arc mRNA induction by $\mathrm{Ca} 2+$ and cAMP requires protein kinase $\mathrm{A}$ and mitogen-activated protein kinase/extracellular regulated kinase activation. J Neurosci 21, 5484-5493.

91. Soule J, Messaoudi E \& Bramham CR (2006) Brain-derived neurotrophic factor and control of synaptic consolidation in the adult brain. Biochem Soc Trans 34, 600-604.

92. Lyford GL, Yamagata K, Kaufmann WE, Barnes CA, Sanders LK, Copeland NG, Gilbert DJ, Jenkins NA, Lanahan AA \& Worley PF (1995) Arc, a growth factor and activity-regulated gene, encodes a novel cytoskeleton-associated protein that is enriched in neuronal dendrites. Neuron 14, 433-445.

93. Reznichenko L, Amit T, Youdim MB \& Mandel S (2005) Green tea polyphenol (-)-epigallocatechin-3-gallate induces neurorescue of long-term serum-deprived PC12 cells and promotes neurite outgrowth. J Neurochem 93, 1157-1167.

94. Hirsch EC, Hunot S \& Hartmann A (2005) Neuroinflammatory processes in Parkinson's disease. Parkinsonism Relat Disord 11, Suppl. 1, S9-S15.

95. McGeer EG \& McGeer PL (2003) Inflammatory processes in Alzheimer's disease. Prog Neuropsychopharmacol Biol Psychiatry 27, 741-749.

96. Zheng Z, Lee JE \& Yenari MA (2003) Stroke: molecular mechanisms and potential targets for treatment. Curr $\mathrm{Mol}$ Med 3, 361-372.

97. Casper D, Yaparpalvi U, Rempel N \& Werner P (2000) Ibuprofen protects dopaminergic neurons against glutamate toxicity in vitro. Neurosci Lett 289, 201-204.

98. Chen H, Zhang SM, Hernan MA, Schwarzschild MA, Willett WC, Colditz GA, Speizer FE \& Ascherio A (2003) Nonsteroidal anti-inflammatory drugs and the risk of Parkinson disease. Arch Neurol 60, 1059-1064.

99. McGeer EG \& McGeer PL (1997) The role of the immune system in neurodegenerative disorders. Mov Disord 12, $855-858$.
100. Vila M, Jackson-Lewis V, Guegan C, Wu DC, Teismann P, Choi DK, Tieu K \& Przedborski S (2001) The role of glial cells in Parkinson's disease. Curr Opin Neurol 14, 483-489.

101. Kim YS \& Joh TH (2006) Microglia, major player in the brain inflammation: their roles in the pathogenesis of Parkinson's disease. Exp Mol Med 38, 333-347.

102. Allan SM \& Rothwell NJ (2003) Inflammation in central nervous system injury. Philos Trans R Soc Lond B Biol Sci $\mathbf{3 5 8}$, 1669-1677.

103. Stewart VC \& Heales SJ (2003) Nitric oxide-induced mitochondrial dysfunction: implications for neurodegeneration. Free Radic Biol Med 34, 287-303.

104. Moncada S \& Bolanos JP (2006) Nitric oxide, cell bioenergetics and neurodegeneration. J Neurochem 97, 1676-1689.

105. Kozuka N, Itofusa R, Kudo Y \& Morita M (2005) Lipopolysaccharide and proinflammatory cytokines require different astrocyte states to induce nitric oxide production. $J$ Neurosci Res 82, 717-728.

106. Bal-Price A, Matthias A \& Brown GC (2002) Stimulation of the NADPH oxidase in activated rat microglia removes nitric oxide but induces peroxynitrite production. $J$ Neurochem $\mathbf{8 0}$, $73-80$.

107. Fiebich BL, Lieb K, Engels S \& Heinrich M (2002) Inhibition of LPS-induced p42/44 MAP kinase activation and iNOS/NO synthesis by parthenolide in rat primary microglial cells. J Neuroimmunol 132, 18-24.

108. Bhat NR, Zhang P, Lee JC \& Hogan EL (1998) Extracellular signal-regulated kinase and p38 subgroups of mitogen-activated protein kinases regulate inducible nitric oxide synthase and tumor necrosis factor-alpha gene expression in endotoxin-stimulated primary glial cultures. J Neurosci $\mathbf{1 8}$ $1633-1641$.

109. Marcus JS, Karackattu SL, Fleegal MA \& Sumners C (2003) Cytokine-stimulated inducible nitric oxide synthase expression in astroglia: role of Erk mitogen-activated protein kinase and NF-kappaB. Glia 41, 152-160.

110. Pawate S \& Bhat NR (2006) C-Jun N-terminal kinase (JNK) regulation of iNOS expression in glial cells: predominant role of JNK1 isoform. Antioxid Redox Signal 8, 903-909.

111. Li R, Huang YG, Fang D \& Le WD (2004) (-)-Epigallocatechin gallate inhibits lipopolysaccharide-induced microglial activation and protects against inflammation-mediated dopaminergic neuronal injury. J Neurosci Res 78, 723-731.

112. Huang Q, Wu LJ, Tashiro S, Gao HY, Onodera S \& Ikejima T (2005) (+)-Catechin, an ingredient of green tea, protects murine microglia from oxidative stress-induced DNA damage and cell cycle arrest. $J$ Pharmacol Sci 98, 16-24.

113. Lee H, Kim YO, Kim H, Kim SY, Noh HS, Kang SS, Cho GJ, Choi WS \& Suk K (2003) Flavonoid wogonin from medicinal herb is neuroprotective by inhibiting inflammatory activation of microglia. FASEB J 17, 1943-1944.

114. Shen SC, Lee WR, Lin HY, Huang HC, Ko CH, Yang LL \& Chen YC (2002) In vitro and in vivo inhibitory activities of rutin, wogonin, and quercetin on lipopolysaccharide-induced nitric oxide and prostaglandin E(2) production. Eur J Pharmacol 446, 187-194.

115. Woo KJ, Lim JH, Suh SI, Kwon YK, Shin SW, Kim SC, Choi YH, Park JW \& Kwon TK (2006) Differential inhibitory effects of baicalein and baicalin on LPS-induced cyclooxygenase-2 expression through inhibition of C/EBPbeta DNA-binding activity. Immunobiology 211, 359-368.

116. Kim H, Kim YS, Kim SY \& Suk K (2001) The plant flavonoid wogonin suppresses death of activated C6 rat glial cells by inhibiting nitric oxide production. Neurosci Lett 309, 67-71.

117. Chen CJ, Raung SL, Liao SL \& Chen SY (2004) Inhibition of inducible nitric oxide synthase expression by baicalein in 
endotoxin/cytokine-stimulated microglia. Biochem Pharmacol 67, 957-965.

118. Chen JC, Ho FM, Pei-Dawn LC, Chen CP, Jeng KC, Hsu HB, Lee ST, Wen TW \& Lin WW (2005) Inhibition of iNOS gene expression by quercetin is mediated by the inhibition of IkappaB kinase, nuclear factor-kappa B and STAT1, and depends on heme oxygenase-1 induction in mouse BV-2 microglia. Eur J Pharmacol 521, 9-20.

119. Matter WF, Brown RF \& Vlahos CJ (1992) The inhibition of phosphatidylinositol 3-kinase by quercetin and analogs. Biochem Biophys Res Commun 186, 624-631.

120. Vlahos CJ, Matter WF, Hui KY \& Brown RF (1994) A specific inhibitor of phosphatidylinositol 3-kinase, 2-(4-morpholinyl)8-phenyl-4H-1-benzopyran-4-one (LY294002). J Biol Chem 269, 5241-5248.

121. Agullo G, Gamet-Payrastre L, Manenti S, Viala C, Remesy C, Chap H \& Payrastre B (1997) Relationship between flavonoid structure and inhibition of phosphatidylinositol 3-kinase: a comparison with tyrosine kinase and protein kinase $\mathrm{C}$ inhibition. Biochem Pharmacol 53, 1649-1657.

122. Gamet-Payrastre L, Manenti S, Gratacap MP, Tulliez J, Chap H \& Payrastre B (1999) Flavonoids and the inhibition of PKC and PI 3-kinase. Gen Pharmacol 32, 279-286.

123. Kong AN, Yu R, Chen C, Mandlekar S \& Primiano T (2000) Signal transduction events elicited by natural products: role of MAPK and caspase pathways in homeostatic response and induction of apoptosis. Arch Pharm Res 23, 1-16.

124. Lin CH, Yeh SH, Lin CH, Lu KT, Leu TH, Chang WC \& Gean PW (2001) A role for the PI-3 kinase signaling pathway in fear conditioning and synaptic plasticity in the amygdala. Neuron 31, 841-851.

125. Sweatt JD (2001) Memory mechanisms: the yin and yang of protein phosphorylation. Curr Biol 11, R391-R394.

126. Conseil G, Baubichon-Cortay H, Dayan G, Jault JM, Barron D \& Di Pietro A (1998) Flavonoids: a class of modulators with bifunctional interactions at vicinal ATP- and steroid-binding sites on mouse P-glycoprotein. Proc Natl Acad Sci U S A 95, 9831-9836.

127. Di Pietro A, Godinot C, Bouillant ML \& Gautheron DC (1975) Pig heart mitochondrial ATPase: properties of purified and membrane-bound enzyme. Effects of flavonoids. Biochimie 57, 959-967.

128. Barzilai A \& Rahamimoff $\mathrm{H}$ (1983) Inhibition of Ca2 + transport ATPase from synaptosomal vesicles by flavonoids. Biochim Biophys Acta 730, 245-254.

129. Revuelta MP, Cantabrana B \& Hidalgo A (1997) Depolarization-dependent effect of flavonoids in rat uterine smooth muscle contraction elicited by $\mathrm{CaCl} 2$. Gen Pharmacol 29, 847-857.

130. Lee SF \& Lin JK (1997) Inhibitory effects of phytopolyphenols on TPA-induced transformation, PKC activation, and c-jun expression in mouse fibroblast cells. Nutr Cancer $\mathbf{2 8}$, $177-183$.

131. Ursini F, Maiorino M, Morazzoni P, Roveri A \& Pifferi G (1994) A novel antioxidant flavonoid (IdB 1031) affecting molecular mechanisms of cellular activation. Free Radic Biol Med 16, 547-553.

132. Kantengwa S \& Polla BS (1991) Flavonoids, but not protein kinase $\mathrm{C}$ inhibitors, prevent stress protein synthesis during erythrophagocytosis. Biochem Biophys Res Commun 180, 308-314.

133. Rosenblat M, Belinky P, Vaya J, Levy R, Hayek T, Coleman R, Merchav S \& Aviram M (1999) Macrophage enrichment with the isoflavan glabridin inhibits NADPH oxidase-induced cell-mediated oxidation of low density lipoprotein. A possible role for protein kinase C. $J$ Biol Chem 274, 13790-13799.
134. Boege F, Straub T, Kehr A, Boesenberg C, Christiansen K, Andersen A, Jakob F \& Kohrle J (1996) Selected novel flavones inhibit the DNA binding or the DNA religation step of eukaryotic topoisomerase I. J Biol Chem 271, 2262-2270.

135. Medina JH, Viola H, Wolfman C, Marder M, Wasowski C, Calvo D \& Paladini AC (1997) Overview-flavonoids: a new family of benzodiazepine receptor ligands. Neurochem Res 22, 419-425.

136. Dekermendjian K, Kahnberg P, Witt MR, Sterner O, Nielsen M \& Liljefors T (1999) Structure-activity relationships and molecular modeling analysis of flavonoids binding to the benzodiazepine site of the rat brain $\mathrm{GABA}(\mathrm{A})$ receptor complex. J Med Chem 42, 4343-4350.

137. Fischer PM \& Lane DP (2000) Inhibitors of cyclin-dependent kinases as anti-cancer therapeutics. Curr Med Chem 7, $1213-1245$.

138. Huang YT, Hwang JJ, Lee PP, Ke FC, Huang JH, Huang CJ, Kandaswami C, Middleton E Jr \& Lee MT (1999) Effects of luteolin and quercetin, inhibitors of tyrosine kinase, on cell growth and metastasis-associated properties in A431 cells overexpressing epidermal growth factor receptor. $\mathrm{Br} \mathrm{J}$ Pharmacol 128, 999-1010.

139. So FV, Guthrie N, Chambers AF, Moussa M \& Carroll KK (1996) Inhibition of human breast cancer cell proliferation and delay of mammary tumorigenesis by flavonoids and citrus juices. Nutr Cancer 26, 167-181.

140. Green DR \& Reed JC (1998) Mitochondria and apoptosis. Science 281, 1309-1312.

141. Tatton WG \& Olanow CW (1999) Apoptosis in neurodegenerative diseases: the role of mitochondria. Biochim Biophys Acta 1410, 195-213.

142. Goyal L (2001) Cell death inhibition: keeping caspases in check. Cell 104, 805-808.

143. Srinivasula SM, Hegde R, Saleh A, et al. (2001) A conserved XIAP-interaction motif in caspase-9 and Smac/DIABLO regulates caspase activity and apoptosis. Nature 410, 112-116.

144. Cobb MH \& Goldsmith EJ (1995) How MAP kinases are regulated. J Biol Chem 270, 14843-14846.

145. Goldsmith EJ \& Cobb MH (1994) Protein kinases. Curr Opin Struct Biol 4, 833-840.

146. Marshall CJ (1994) Signal transduction. Hot lips and phosphorylation of protein kinases. Nature $\mathbf{3 6 7}, 686$

147. Karin M (1995) The regulation of AP-1 activity by mitogenactivated protein kinases. J Biol Chem 270, 16483-16486.

148. Xia Z, Dickens M, Raingeaud J, Davis RJ \& Greenberg ME (1995) Opposing effects of ERK and JNK-p38 MAP kinases on apoptosis. Science 270, 1326-1331.

149. Anderson CN \& Tolkovsky AM (1999) A role for MAPK/ERK in sympathetic neuron survival: protection against a p53dependent, JNK-independent induction of apoptosis by cytosine arabinoside. J Neurosci 19, 664-673.

150. Bonni A, Brunet A, West AE, Datta SR, Takasu MA \& Greenberg ME (1999) Cell survival promoted by the Ras-MAPK signaling pathway by transcription-dependent and -independent mechanisms. Science 286, 1358-1362.

151. Kaplan DR \& Miller FD (2000) Neurotrophin signal transduction in the nervous system. Curr Opin Neurobiol 10, 381-391.

152. Crossthwaite AJ, Hasan S \& Williams RJ (2002) Hydrogen peroxide-mediated phosphorylation of ERK1/2, Akt/PKB and JNK in cortical neurones: dependence on $\mathrm{Ca}(2+)$ and PI3-kinase. J Neurochem 80, 24-35.

153. Mielke K \& Herdegen T (2000) JNK and p38 stresskinasesdegenerative effectors of signal-transduction-cascades in the nervous system. Prog Neurobiol 61, 45-60.

154. Yuan J \& Yankner BA (2000) Apoptosis in the nervous system. Nature 407, 802-809. 
155. Behrens A, Sibilia M \& Wagner EF (1999) Amino-terminal phosphorylation of c-Jun regulates stress-induced apoptosis and cellular proliferation. Nat Genet 21, 326-329.

156. Davis RJ (2000) Signal transduction by the JNK group of MAP kinases. Cell 103, 239-252.

157. Kobuchi H, Roy S, Sen CK, Nguyen HG \& Packer L (1999) Quercetin inhibits inducible ICAM-1 expression in human endothelial cells through the JNK pathway. Am J Physiol 277, C403-C411.

158. Herdegen T, Skene P \& Bahr M (1997) The c-Jun transcription factor-bipotential mediator of neuronal death, survival and regeneration. Trends Neurosci 20, 227-231.

159. Castagne V \& Clarke PG (1999) Inhibitors of mitogenactivated protein kinases protect axotomized developing neurons. Brain Res 842, 215-219.

160. Castagne V, Gautschi M, Lefevre K, Posada A \& Clarke PG (1999) Relationships between neuronal death and the cellular redox status. Focus on the developing nervous system. Prog Neurobiol 59, 397-423.

161. Hung SP, Hsu JR, Lo CP, Huang HJ, Wang JP \& Chen ST (2005) Genistein-induced neuronal differentiation is associated with activation of extracellular signal-regulated kinases and upregulation of $\mathrm{p} 21$ and N-cadherin. $J$ Cell Biochem 96, 1061-1070.

162. Llorens F, Garcia L, Itarte E \& Gomez N (2002) Apigenin and LY294002 prolong EGF-stimulated ERK1/2 activation in PC12 cells but are unable to induce full differentiation. FEBS Lett 510, 149-153.

163. Dudley DT, Pang L, Decker SJ, Bridges AJ \& Saltiel AR (1995) A synthetic inhibitor of the mitogen-activated protein kinase cascade. Proc Natl Acad Sci U S A 92, 7686-7689.

164. Pang L, Sawada T, Decker SJ \& Saltiel AR (1995) Inhibition of MAP kinase kinase blocks the differentiation of PC-12 cells induced by nerve growth factor. $J$ Biol Chem 270, 13585-13588.

165. Alessi DR, Cuenda A, Cohen P, Dudley DT \& Saltiel AR (1995) PD 098059 is a specific inhibitor of the activation of mitogen-activated protein kinase kinase in vitro and in vivo. J Biol Chem 270, 27489-27494.

166. Lazar DF, Wiese RJ, Brady MJ, Mastick CC, Waters SB, Yamauchi K, Pessin JE, Cuatrecasas P \& Saltiel AR (1995) Mitogen-activated protein kinase kinase inhibition does not block the stimulation of glucose utilization by insulin. $J$ Biol Chem 270, 20801-20807.

167. Levites Y, Amit T, Youdim MB \& Mandel S (2002) Involvement of protein kinase $\mathrm{C}$ activation and cell survival/cell cycle genes in green tea polyphenol (-)-epigallocatechin 3-gallate neuroprotective action. J Biol Chem 277, 30574-30580.

168. Reznichenko L, Amit T, Youdim MB \& Mandel S (2005) Green tea polyphenol (-)-epigallocatechin-3-gallate induces neurorescue of long-term serum-deprived PC12 cells and promotes neurite outgrowth. J Neurochem 93, 1157-1167.

169. Walker EH, Pacold ME, Perisic O, Stephens L, Hawkins PT, Wymann MP \& Williams RL (2000) Structural determinants of phosphoinositide 3-kinase inhibition by wortmannin, LY294002, quercetin, myricetin, and staurosporine. Mol Cell 6, 909-919.

170. Perkinton MS, Sihra TS \& Williams RJ (1999) $\mathrm{Ca}(2+)$ permeable AMPA receptors induce phosphorylation of cAMP response element-binding protein through a phosphatidylinositol 3-kinase-dependent stimulation of the mitogenactivated protein kinase signaling cascade in neurons. J Neurosci 19, 5861-5874.

171. Jacobson KA, Moro S, Manthey JA, West PL \& Ji XD (2002) Interactions of flavones and other phytochemicals with adenosine receptors. Adv Exp Med Biol 505, 163-171.

172. Johnston GA (2005) GABA(A) receptor channel pharmacology. Curr Pharm Des 11, 1867-1885.
173. Adachi N, Tomonaga S, Tachibana T, Denbow DM \& Furuse M (2006) (-)-Epigallocatechin gallate attenuates acute stress responses through GABAergic system in the brain. Eur $J$ Pharmacol 531, 171-175.

174. Han YS, Bastianetto S, Dumont Y \& Quirion R (2006) Specific plasma membrane binding sites for polyphenols, including resveratrol, in the rat brain. J Pharmacol Exp Ther 318, 238-245.

175. Nifli AP, Bosson-Kouame A, Papadopoulou N, Kogia C, Kampa M, Castagnino C, Stournaras C, Vercauteren J \& Castanas E (2005) Monomeric and oligomeric flavanols are agonists of membrane androgen receptors. Exp Cell Res $\mathbf{3 0 9}$, 329-339.

176. Klinge CM, Blankenship KA, Risinger KE, Bhatnagar S, Noisin EL, Sumanasekera WK, Zhao L, Brey DM \& Keynton RS (2005) Resveratrol and estradiol rapidly activate MAPK signaling through estrogen receptors alpha and beta in endothelial cells. $J$ Biol Chem 280, 7460-7468.

177. Camps M, Nichols A \& Arkinstall S (2000) Dual specificity phosphatases: a gene family for control of MAP kinase function. FASEB $J$ 14, 6-16.

178. Kim Y, Rice AE \& Denu JM (2003) Intramolecular dephosphorylation of ERK by MKP3. Biochemistry 42, 15197-15207.

179. Davis RJ (1999) Signal transduction by the c-Jun N-terminal kinase. Biochem Soc Symp 64, 1-12.

180. Leppa S \& Bohmann D (1999) Diverse functions of JNK signaling and c-Jun in stress response and apoptosis. Oncogene 18, 6158-6162.

181. Ichijo H (1999) From receptors to stress-activated MAP kinases. In Oncogene 18, pp. 6087-6093.

182. Ichijo H, Nishida E, Irie K, ten Dijke P, Saitoh M, Moriguchi T, Takagi M, Matsumoto K, Miyazono K \& Gotoh Y (1997) Induction of apoptosis by ASK1, a mammalian MAPKKK that activates SAPK/JNK and p38 signaling pathways. Science $\mathbf{2 7 5}, 90-94$.

183. Wang XS, Diener K, Jannuzzi D, Trollinger D, Tan TH, Lichenstein H, Zukowski M \& Yao Z (1996) Molecular cloning and characterization of a novel protein kinase with a catalytic domain homologous to mitogen-activated protein kinase kinase kinase. J Biol Chem 271, 31607-31611.

184. Matsuzawa A \& Ichijo H (2001) Molecular mechanisms of the decision between life and death: regulation of apoptosis by apoptosis signal-regulating kinase 1. J Biochem (Tokyo) 130, 1-8.

185. Schroeter H, Williams RJ, Matin R, Iversen L \& Rice-Evans CA (2000) Phenolic antioxidants attenuate neuronal cell death following uptake of oxidized low-density lipoprotein. Free Radic Biol Med 29, 1222-1233.

186. Spencer JPE, Schroeter H, Kuhnle G, Srai SK, Tyrrell RM, Hahn U \& Rice-Evans C (2001) Epicatechin and its in vivo metabolite, $3^{\prime}-O$-methyl epicatechin, protect human fibroblasts from oxidative-stress-induced cell death involving caspase-3 activation. Biochem J 354, 493-500.

187. Wang L, Matsushita K, Araki I \& Takeda M (2002) Inhibition of c-Jun N-terminal kinase ameliorates apoptosis induced by hydrogen peroxide in the kidney tubule epithelial cells (NRK-52E). Nephron 91, 142-147.

188. Ishikawa Y \& Kitamura M (2000) Anti-apoptotic effect of quercetin: intervention in the JNK- and ERK-mediated apoptotic pathways. Kidney Int 58, 1078-1087.

189. Uchida K, Shiraishi M, Naito Y, Torii Y, Nakamura Y \& Osawa T (1999) Activation of stress signaling pathways by the end product of lipid peroxidation. 4-Hydroxy-2-nonenal is a potential inducer of intracellular peroxide production. J Biol Chem 274, 2234-2242.

190. Zhang L, Chen J \& Fu H (1999) Suppression of apoptosis signal-regulating kinase 1-induced cell death by 14-3-3 proteins. Proc Natl Acad Sci U S A 96, 8511-8515. 
191. Park HS, Park E, Kim MS, Ahn K, Kim IY \& Choi EJ (2000) Selenite inhibits the c-Jun N-terminal kinase/stress-activated protein kinase (JNK/SAPK) through a thiol redox mechanism. J Biol Chem 275, 2527-2531.

192. Adler V, Yin Z, Fuchs SY, et al. (1999) Regulation of JNK signaling by GSTp. EMBO J 18, 1321-1334.

193. Adler V, Yin Z, Tew KD \& Ronai Z (1999) Role of redox potential and reactive oxygen species in stress signaling. Oncogene 18, 6104-6111.

194. Monaco R, Friedman FK, Hyde MJ, Chen JM, Manolatus S, Adler V, Ronai Z, Koslosky W \& Pincus MR (1999) Identification of a glutathione- $S$-transferase effector domain for inhibition of jun kinase, by molecular dynamics. $J$ Protein Chem 18, 859-866.

195. Yin Z, Ivanov VN, Habelhah H, Tew K \& Ronai Z (2000) Glutathione S-transferase $p$ elicits protection against $\mathrm{H} 2 \mathrm{O} 2$ induced cell death via coordinated regulation of stress kinases. Cancer Res 60, 4053-4057.

196. Spencer JPE, Abd El, Mohsen MM \& Rice-Evans C (2003) Cellular uptake and metabolism of flavonoids and their metabolites: implications for their bioactivity. Arch Biochem Biophys 423, $148-161$.

197. Kennedy SG, Wagner AJ, Conzen SD, Jordan J, Bellacosa A, Tsichlis PN \& Hay N (1997) The PI 3-kinase/Akt signaling pathway delivers an anti-apoptotic signal. Genes Dev 11, 701-713.

198. Coffer PJ, Jin J \& Woodgett JR (1998) Protein kinase B (c-Akt): a multifunctional mediator of phosphatidylinositol 3-kinase activation. Biochem J 335, [Pt 1], 1-13.

199. Miller FD \& Kaplan DR (2001) Neurotrophin signalling pathways regulating neuronal apoptosis. Cell Mol Life Sci 58, $1045-1053$

200. Crowder RJ \& Freeman RS (1998) Phosphatidylinositol 3-kinase and Akt protein kinase are necessary and sufficient for the survival of nerve growth factor-dependent sympathetic neurons. J Neurosci 18, 2933-2943.

201. Carpenter CL \& Cantley LC (1990) Phosphoinositide kinases. Biochemistry 29, 11147-11156.

202. Simpson L \& Parsons R (2001) PTEN: life as a tumor suppressor. Exp Cell Res 264, 29-41.

203. Neri LM, Borgatti P, Capitani S \& Martelli AM (2002) The nuclear phosphoinositide 3-kinase/AKT pathway: a new second messenger system. Biochim Biophys Acta 1584, 73-80.

204. Franke TF, Kaplan DR \& Cantley LC (1997) PI3K: downstream AKTion blocks apoptosis. Cell 88, 435-437.

205. Burgering BM \& Coffer PJ (1995) Protein kinase B (c-Akt) in phosphatidylinositol-3-OH kinase signal transduction. Nature 376, 599-602.

206. Franke TF, Yang SI, Chan TO, Datta K, Kazlauskas A, Morrison DK, Kaplan DR \& Tsichlis PN (1995) The protein kinase encoded by the Akt proto-oncogene is a target of the PDGF-activated phosphatidylinositol 3-kinase. Cell 81, $727-736$.

207. Cardone MH, Roy N, Stennicke HR, Salvesen GS, Franke TF, Stanbridge E, Frisch S \& Reed JC (1998) Regulation of cell death protease caspase-9 by phosphorylation. Science $\mathbf{2 8 2}$, $1318-1321$.

208. Burgering BM \& Kops GJ (2002) Cell cycle and death control: long live Forkheads. Trends Biochem Sci 27, 352-360.

209. Brunet A, Bonni A, Zigmond MJ, Lin MZ, Juo P, Hu LS, Anderson MJ, Arden KC, Blenis J \& Greenberg ME (1999) Akt promotes cell survival by phosphorylating and inhibiting a Forkhead transcription factor. Cell 96, 857-868.

210. Zha J, Harada H, Yang E, Jockel J \& Korsmeyer SJ (1996) Serine phosphorylation of death agonist BAD in response to survival factor results in binding to 14-3-3 not BCL-X(L). Cell 87, 619-628.
211. Alessi DR, Andjelkovic M, Caudwell B, Cron P, Morrice N, Cohen P \& Hemmings BA (1996) Mechanism of activation of protein kinase $\mathrm{B}$ by insulin and IGF-1. EMBO J 15, 6541-6551.

212. Datta SR, Dudek H, Tao X, Masters S, Fu H, Gotoh Y \& Greenberg ME (1997) Akt phosphorylation of BAD couples survival signals to the cell-intrinsic death machinery. Cell 91, 231-241.

213. del Peso L, Gonzalez-Garcia M, Page C, Herrera R \& Nunez G (1997) Interleukin-3-induced phosphorylation of BAD through the protein kinase Akt. Science 278, 687-689.

214. Ferriola PC, Cody V \& Middleton E Jr (1989) Protein kinase C inhibition by plant flavonoids. Kinetic mechanisms and structure-activity relationships. Biochem Pharmacol 38, $1617-1624$.

215. Cao F, Jin TY \& Zhou YF (2006) Inhibitory effect of isoflavones on prostate cancer cells and PTEN gene. Biomed Environ Sci 19, 35-41.

216. Gulati N, Laudet B, Zohrabian VM, Murali R \& JhanwarUniyal M (2006) The antiproliferative effect of Quercetin in cancer cells is mediated via inhibition of the PI3K-Akt/PKB pathway. Anticancer Res 26, 1177-1181.

217. Dave B, Eason RR, Till SR, Geng Y, Velarde MC, Badger TM \& Simmen RC (2005) The soy isoflavone genistein promotes apoptosis in mammary epithelial cells by inducing the tumor suppressor PTEN. Carcinogenesis 26, 1793-1803.

218. Cantley LC \& Neel BG (1999) New insights into tumor suppression: PTEN suppresses tumor formation by restraining the phosphoinositide 3-kinase/AKT pathway. Proc Natl Acad Sci U S A 96, 4240-4245.

219. Myers MP, Pass I, Batty IH, Van der KJ KJ, Stolarov JP, Hemmings BA, Wigler MH, Downes CP \& Tonks NK (1998) The lipid phosphatase activity of PTEN is critical for its tumor supressor function. Proc Natl Acad Sci U S A 95, $13513-13518$.

220. Wu X, Senechal K, Neshat MS, Whang YE \& Sawyers CL (1998) The PTEN/MMAC1 tumor suppressor phosphatase functions as a negative regulator of the phosphoinositide 3-kinase/Akt pathway. Proc Natl Acad Sci U S A 95, 15587-15591.

221. Wild AC, Moinova HR \& Mulcahy RT (1999) Regulation of gamma-glutamylcysteine synthetase subunit gene expression by the transcription factor Nrf2. J Biol Chem 274, 33627-33636.

222. Moinova HR \& Mulcahy RT (1999) Up-regulation of the human gamma-glutamylcysteine synthetase regulatory subunit gene involves binding of Nrf-2 to an electrophile responsive element. Biochem Biophys Res Commun 261, 661-668.

223. Venugopal R \& Jaiswal AK (1998) Nrf2 and Nrf1 in association with Jun proteins regulate antioxidant response element-mediated expression and coordinated induction of genes encoding detoxifying enzymes. Oncogene 17, $3145-3156$.

224. Venugopal R \& Jaiswal AK (1996) Nrf1 and Nrf2 positively and c-Fos and Fra1 negatively regulate the human antioxidant response element-mediated expression of $\mathrm{NAD}(\mathrm{P}) \mathrm{H}$ :quinone oxidoreductase1 gene. Proc Natl Acad Sci U S A 93, 14960-14965.

225. Kang KW, Lee SJ \& Kim SG (2005) Molecular mechanism of nrf2 activation by oxidative stress. Antioxid Redox Signal 7, $1664-1673$.

226. Itoh K, Tong KI \& Yamamoto M (2004) Molecular mechanism activating Nrf2-Keap1 pathway in regulation of adaptive response to electrophiles. Free Radic Biol Med 36, $1208-1213$.

227. Leung L, Kwong M, Hou S, Lee C \& Chan JY (2003) Deficiency of the Nrf1 and Nrf2 transcription factors results 
in early embryonic lethality and severe oxidative stress. $J$ Biol Chem 278, 48021-48029.

228. Bloom D, Dhakshinamoorthy S \& Jaiswal AK (2002) Sitedirected mutagenesis of cysteine to serine in the DNA binding region of Nrf2 decreases its capacity to upregulate antioxidant response element-mediated expression and antioxidant induction of $\mathrm{NAD}(\mathrm{P}) \mathrm{H}$ :quinone oxidoreductase 1 gene. Oncogene 21, 2191-2200.

229. Andreadi CK, Howells LM, Atherfold PA \& Manson MM (2006) Involvement of Nrf2, p38, B-Raf, and nuclear factorkappaB, but not phosphatidylinositol 3-kinase, in induction of hemeoxygenase-1 by dietary polyphenols. Mol Pharmacol 69, $1033-1040$.

230. Banning A, Deubel S, Kluth D, Zhou Z \& Brigelius-Flohe R (2005) The GI-GPx gene is a target for Nrf2. Mol Cell Biol 25, 4914-4923.

231. Hernandez-Montes E, Pollard SE, Vauzour D, Jofre-Montseny L, Rota C, Rimbach G, Weinberg PD \& Spencer JP (2006) Activation of glutathione peroxidase via Nrf1 mediates genistein's protection against oxidative endothelial cell injury. Biochem Biophys Res Commun 346, 851-859.

232. Itoh K, Wakabayashi N, Katoh Y, Ishii T, Igarashi K, Engel JD \& Yamamoto M (1999) Keap1 represses nuclear activation of antioxidant responsive elements by Nrf2 through binding to the amino-terminal Neh2 domain. Genes Dev 13, 76-86.

233. Hayes JD \& McMahon M (2001) Molecular basis for the contribution of the antioxidant responsive element to cancer chemoprevention. Cancer Lett 174, 103-113.

234. Alcaraz MJ, Vicente AM, Araico A, Dominguez JN, Terencio MC \& Ferrandiz ML (2004) Role of nuclear factor-kappaB and heme oxygenase- 1 in the mechanism of action of an anti-inflammatory chalcone derivative in RAW 264.7 cells. Br J Pharmacol 142, 1191-1199.
235. Kobayashi M \& Yamamoto M (2005) Molecular mechanisms activating the Nrf2-Keap1 pathway of antioxidant gene regulation. Antioxid Redox Signal 7, 385-394.

236. Nguyen T, Sherratt PJ, Huang HC, Yang CS \& Pickett CB (2003) Increased protein stability as a mechanism that enhances Nrf2-mediated transcriptional activation of the antioxidant response element. Degradation of Nrf2 by the $26 \mathrm{~S}$ proteasome. J Biol Chem 278, 4536-4541.

237. Nguyen T, Huang HC \& Pickett CB (2000) Transcriptional regulation of the antioxidant response element. Activation by $\mathrm{Nrf} 2$ and repression by MafK. $J$ Biol Chem 275, 15466-15473.

238. Sherratt PJ, Huang HC, Nguyen T \& Pickett CB (2004) Role of protein phosphorylation in the regulation of NF-E2-related factor 2 activity. Methods Enzymol 378, 286-301.

239. Yu R, Mandlekar S, Lei W, Fahl WE, Tan TH \& Kong AN (2000) p38 mitogen-activated protein kinase negatively regulates the induction of phase II drug-metabolizing enzymes that detoxify carcinogens. J Biol Chem 275, 2322-2327.

240. Shen G, Hebbar V, Nair S, Xu C, Li W, Lin W, Keum YS, Han J, Gallo MA \& Kong AN (2004) Regulation of Nrf2 transactivation domain activity. The differential effects of mitogenactivated protein kinase cascades and synergistic stimulatory effect of Raf and CREB-binding protein. J Biol Chem 279, 23052-23060.

241. Kang KW, Lee SJ, Park JW \& Kim SG (2002) Phosphatidylinositol 3-kinase regulates nuclear translocation of NF-E2related factor 2 through actin rearrangement in response to oxidative stress. Mol Pharmacol 62, 1001-1010.

242. Nakaso K, Yano H, Fukuhara Y, Takeshima T, Wada-Isoe K \& Nakashima K (2003) PI3K is a key molecule in the Nrf2mediated regulation of antioxidative proteins by hemin in human neuroblastoma cells. FEBS Lett 546, 181-184. 